\title{
Okul Öncesi ve İlkokul Öğrencilerindeki Allah Tahayyülünün İncelenmesi
}

\author{
Muhammet Ü. Öztabak ${ }^{1}$ Suat Altıntaş²
}

\begin{abstract}
$\ddot{O}_{z}$
Bu araştırmada, okul öncesi çocukları (5-6 yaş) ile okul dönemi çocuklarının (7-8 yaş) Allah tahayyülleri hakkındaki bilgi edinmek amaçlanmıştır. Araştırmada, nitel araştırma yöntemlerinden olgubilim deseni kullanılmıştır. Araştırmanın çalışma grubu, 50'si 5-6 yaş okul öncesi öğrencisi, 50'si 7-8 yaş okul dönemi öğrencisi olmak üzere toplam 100 öğrenciden oluşmaktadır. Öğrencilerle birebir görüşme yapılarak veri toplanmıştır. Veriler içerik analizi yöntemiyle analiz edilmiştir. Elde edilen verilere göre çocukların büyük çoğunluğu (\% 87) Allah’ı tanıdığını ifade ederken, yine çocukların büyük çoğunluğunun Allah'ı anne ve babalarından öğrendikleri sonucuna ulaşı1mıştır. 5-8 yaş çocuklarının Allah'ın nasıl olduğuna ilişkin algılarına genel olarak bakıldığında, 5 yaş çocuklarında Allah insana benzetilmektedir yani Allah tahayyülü antropomorfisttir. 6 yaşta ise Allah'ın daha çok büyüklüğü ve iyiliği üzerinde durulduğu gözlenmektedir. 7 yaş çocuklarında ise Allah büyüklük özelliği ve gökyüzü ile eşleştirilmiştir. Bunun sebebi gökyüzünün sonsuza açılması, uçsuz bucaksızlığı ve Tanrı'nın yüceliğine işaret ettiği için metaforik olarak çocuklarda sıklıkla kullanıldığ görülmektedir. 8 yaşta ise insana benzetme tekrar ön plana çıkmaktadır.
\end{abstract}

\section{Anahtar Kelimeler}

Allah tahayyülü, Allah tasavvuru, din eğitimi, okul öncesi, çocuk.

1 Yetkilendirilmiş yazar: Muhammet Ü. Öztabak, Fatih Sultan Mehmet Vakıf Üniversitesi Eğitim Fakültesi Eğitim Bilimleri Bölümü, Rehberlik ve Psikolojik Danışmanlık Anabilim Dalı, İstanbul/ Türkiye, E-posta: muoztabak@fsm.edu.tr, ORCID ID: 0000-0003-4923-2163

2. Milli Eğitim Bakanlığı Eğitim Yöneticisi, İstanbul/Türkiye, E-posta: altintassuat88@hotmail.com, ORCID ID: 0000-0002-9303-4650 


\title{
Investigation of the Imagination of Allah in Preschool and Primary School Students
}

\author{
Muhammet Ü. Öztabak Suat Altıntaş
}

\begin{abstract}
This research aims to learn about preschool children (5-6 years) and school children (7-8 years) about the imaginations of Allah. The phenomenological research design was used as a part of qualitative research method. The study group consists of 100 students, 50 of whom are 5-6 years old preschool students and 50 of them 7-8 years old school period students. The data was collected through one-on-one interviews with students. The data was analyzed by content analysis method. According to the data obtained, while the vast majority of children (87\%) stated that they knew God, it was concluded that the vast majority of children learned Allah from their parents. When we look at the perceptions of children about how God is, Allah is compared to human in 5 years old children, in short the imagination of children about Allah is anthropomorphist. At the age of 6 , it is observed that the greatness and well-being of God is emphasized. In the children of 7 years old, Allah is matched with the greatness and sky. The reason for this is that the opening of the sky to infinity indicates God's glory, so it can be used metaphorically in children. At the age of 8, the analogy to the human comes to the fore again.
\end{abstract}

\section{Keywords}

God imagination, religious education, preschool, student, child.

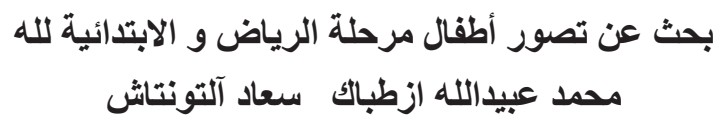

\section{الخلاصة}

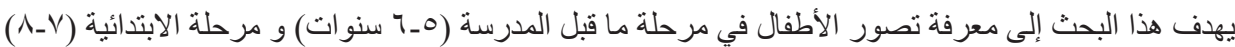

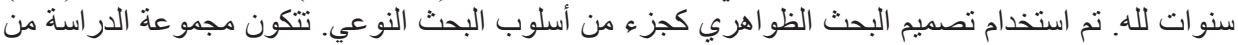

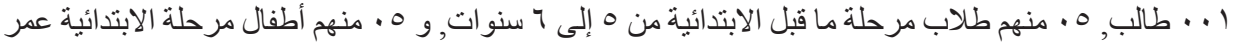

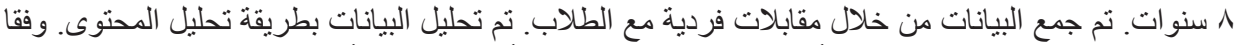

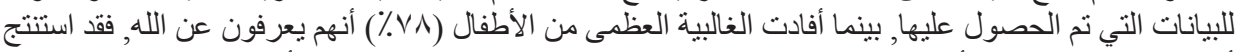

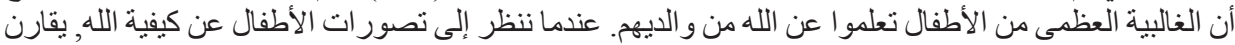

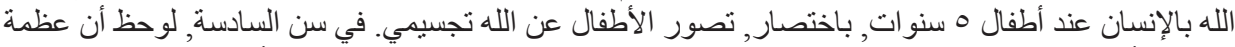

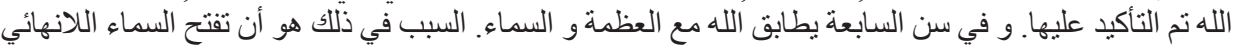

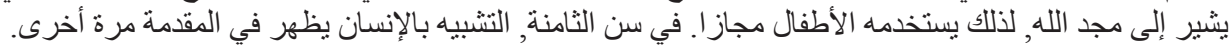
الكلمات المفتاحية

$$
\text { تصور الله, تربية دينية, حضانة, طالب, طفل. }
$$




\section{Giriş}

İnsanların inanma ihtiyacı yaradılıştan (fitrat) gelmektedir. İlk insandan günümüze kadar hiçbir çağda dinsiz bir toplum yaşamamıştır (Öcal, 2004). İnsanlar, doğuştan Allah'a inanmaya yetenekli ve dini inancı kabullenmeye elverişli yaratılıştadır (Ay, 1993). Hz. Peygamber'in (s.a.v.) «Her doğan fitrat üzere doğar, sonra ebeveyni onu Yahudi, Hiristiyan, Mecusi yapar" (Buhari, 1981) hadisinde fitratın hem doğuştan geldiği hem de evrensel nitelikte olduğundan bahsedilmektedir. Fitrat ile kastedilenin anlamı konusunda farklı açıklamalar bulunsa da bu kavram, her insanın metafizik kurguya yönelttiği bir inancının bulunduğuna işaret etmektedir.

Tanrı tasavvuru insanların spiritüel (manevi) yaşantısında yer alan yapılar arasında oldukça önemli bir konuma sahiptir. Çünkü Tanrı'ya ilişkin düşünceler, inanç dünyasının odak noktasıdır ve dolayısıyla bireylerin değerlerini ve düşünsel dünyalarını şekillendiren kurucu etmendir (Evkuran, 2007). Bireyin sahip olduğu Tanrı tasavvuru, onun diğer bütün dini tasavvurlarını ve varlıklar arasındaki ilişki biçimlerini şekillendirdiği için de ayrıca önemlidir (Bedir, 2017). Tanrı tasavvuru bireyin hayatında dikkate değer bir etkiye sahip olduğundan pek çok araştırmanın konusu haline gelişmiştir. İnanan insanların dünyasındaki etki alanın büyüklüğü elinizdeki çalışmanın oluşturulmasında da başat sebebi oluşturmaktadır. Bu çalışmanın amacı Tanrı fikrine aşina bir toplumda dünyaya gelen çocukların nasıl bir Tanrı tahayyülüne sahip olduğunu ortaya koymaktır. $\mathrm{Bu}$ düşünceden hareketle çocuklarda Tanrı fikrinin nasıl geliştiği, hangi psikolojik ve sosyolojik olgularla ilişki içerisinde olduğu ve bu olguların çocuklarda ne tür farklılıklar oluşturduğu gösterilmeye çalışlacaktır. Bu verilerin anlaşılır bir şekilde ortaya konulması için öncelikle konuyla ilgili çalışmalarda kullanılan terimsel ifadeler ele alınacak ardından Tanrı kavramı hakkında teolojik-etimolojik bir açıklamadan sonra araştırmamızın verileri aktarılacaktır. Ve son olarak bu veriler ışığında ulaştığımız sonuçlar tartışmaya açılacaktır.

Tanrı tasavvurunu inceleyen araştırmacılar, kişilerin Tanrı hakkındaki fikirlerini ifade etmek için farklı ifadelere başvurmakta ve söz konusu bu ifadeler arasında herhangi bir ayrım gütmeden birbirlerinin yerine kullanmaktadırlar. (Grimes, 2007). Söz konusu ifadeler Tanrı tasavvuru, Tanrı kavramı ve Tanrı imajı gibi farklı çağrışımlara sahip ikilemelerden oluşmaktadır. Fakat bu üç ifadenin etimolojik tazammunları birbirinden dikkate değer ölçüde farklılaşmaktadır. Dolayısıyla araştırmanın kapsamını doğru ifade etmesi bakımından öncelikle konuya en uygun ifadenin hangisi olduğuna karar verilmelidir. Tanrı hakkındaki fikirlerin ortaya konulmaya çalışıldığı din psikolojisi literatüründe Tanrı hakkındaki fikirleri belirtmek için Rizzuto'nun tasnifi kullanılmaktadır. $\mathrm{Bu}$ tasnifinde Rizzuto, Tanrı'ya dair duygusal deneyimleri Tanrı tasavvuru olarak tanımlamakta, duygusal deneyimlerden daha ileri aşama olan bilişsel süreçlerin ürününü ise Tanrı kavramı olarak kavramsallaştırmaktadır. Daha açık bir ifadeyle Rizzuto'ya göre Tanrı tasavvuru bireyin çocukluk dönemindeki hayal ve imajların birleşiminden oluşurken Tanrı kavramı bütün entelektüel süreçlerin 
dahil edilerek oluşturulduğu kanaati temsil etmektedir (Mehmedoğlu, 2011). Nitekim Rizzuto'yu destekler mahiyette Ruchgy, Tanrı kavramının Tanrı'nın bilince yansımasını ifade ederken, Tanrı tasavvurunun ise çocukluk yaşantımızın duygularının içinde bulunduğunu belirtir (Ruchgy, 2004). Benzer biçimde Yıldız (2007) da Tanrı tasavvurunun temelinin çocukluk döneminde atıldığını belirtmektedir. Özetle Rizzuto'nun oluşturduğu ve literatürde kabul edilen bu tasnife göre Tanrı tasavvuru çocukluk döneminde oluşturulan bir algıyı ifade ederken; Tanrı kavramı soyut düşünme yetisine sahip yetişkin bireylerin Tanrı hakkındaki kanaatlerini belirtmektedir.

Rizzuto'nun oluşturduğu ikili tasnif her ne kadar literatürde yoğun biçimde kullanılsa da bu tasnif kavram ve tasavvur kelimelerinin etimolojik anlamları açısından birtakım sınırlılıklar içermektedir. Zira Rizzuto'nun Tanrı tasavvuru için yaptığı açıklama tasavvur kelimesinin içeriği ile birlikte düşünüldüğünde pek isabetli görünmemektedir. Buna göre tasavvur kelimesi her ne kadar "zihinde canlandırma, tasarım, gözünde canlandırma" gibi anlamlara gelse de "hayal etme" anlamındaki tahayyül kelimesinden ayrılmaktadır. Tahayyül kelimesi "hayal etmek, soyut olan bir şeyi somut varlıklar vasıtasıyla düşünmek" anlamına gelir. ${ }^{2} \mathrm{Bu}$ anlamda tasavvur kelimesi tahayyül kelimesinden ayrılır. Çünkü tasavvur soyut bir şeyin somut varlıklar olarak hayal edilmesinden çok soyut işlemler dönemindeki bireyin bütün entelektüel süreçlerini dahil ederek oluşturduğu soyut bir şeyi kavramsallaştırmasına işaret eder. ${ }^{3} \mathrm{Bu}$ anlamda tasavvur bireyin tüm birikimlerinden hareketle zihninde zaten soyut olan bir fikri kavrama dökmesi anlamına gelmektedir. Dolayısıyla tasavvur kelimesinin psikoloji literatüründe kendisine atfedilen anlamından daha soyut bir içeriğe sahip olması Rizzuto'nun tasnifini kullanışsız hale getirmektedir. Tasavvurun bu anlamı dikkate alındığında Tanrı tasavvurunun duygusal birikimler ve çocukluk hayalleri olarak tanımlanması kelimenin etimolojik karakterine uymayacaktır. Çünkü çocukların Tanrı hakkındaki fikirleri tasavvurla değil tahayyülle oluşturdukları imajlardan ibarettir. Yani çocuk Tanrı hakkında soyut fikirlere sahip olmadığı için bir tasavvur oluşturamaz, o

2 Arapçada "zannetmek ve benzetmek" anlamlarına gelen hayl (hayelân) kökünden gelen bir isimdir. Hayâl ve hayâlet, uyku yahut uyanıklık halinde insana gerçekmiş gibi görünen sûrettir. Burada söz konusu olan gerçek değil gerçeğin gölgesi, aynadaki yansıması veya rüyadaki timsalidir. Dolayısıyla hayal sözlükte "bir şeyin gerçeği zannedilen veya gerçeğine benzeyen, benzetilen görüntüsü" anlamına gelir ve tahayyül, zan, teşebbüh kelimeleriyle aynı veya yakın anlamda kullanılır (Lisânü’l'Arab, "hyl" md.).

Ali Durusoy, (1998) “Hayal”, Türkiye Diyanet Vakfı İslâm Ansiklopedisi, https://islamansiklopedisi.org. tr/hayal

3 Sözlükte "bir şeyi zihinde canlandırmak, tasarlamak" anlamındaki tasavvur herhangi bir varlık hakkında bilgi edinme sürecinde ilk aşamayı oluşturur. Bu anlamıyla tasavvura mefhûm da denir. Felsefeciler, zihindeki deney öncesi (önsel, kablî, apriori) tasavvurlarla deney sonrası (ba'dî, aposteriori) oluşan tasavvurlar arasında bir ayırım yaparlar. İdealistler varlık, zorunluluk, imkân, birlik ve çokluk gibi önsel tasavvurların salt ve gerçek olduğunu savunurken deneyciler insan, hayvan, bitki ve bir varlığın deney sonrası zihindeki mâna ve tasavvurunun gerçek tasavvur olduğunu söyleyerek önsel tasavvurların varlığını kabule yanaşmazlar. Rasyonalistler ise gerçek sayılmaya en lâyık olanın önsel tasavvurlar olduğu iddiasındadır (Cemîl Salîbâ, I, 281).

Cemîl Salîbâ, el-Mu 'cemü'l-felsefî, Beyrut 1982, I, 281.

Mahmut Kaya, (2011) “Tasavvur”, TDV İslâm Ansiklopedisi, https://islamansiklopedisi.org.tr/tasavvur 
ancak tahayyül edebilir. Dolayısıyla bu çalışmada çocukların bu bilişsel sınırlılıkları göz önüne alınarak Tanrı hakkındaki fikirlerini ifade etmek için tahayyül kavramı kullanılacaktır.

Çalışmada açıklık getirilmesi gereken bir diğer kavram Tanrı kavramıdır. Tanrı kavramı monoteistik ve politeistik inanç sistemlerinde farklı özelliklere sahip olmakla birlikte evrenin yaratıcısı olduğu düşünülen doğa üstü bir varlığı ifade eder. Bu çalışmada Tanrı kavramı ile teistik Tanrı kastedilmektedir. Bir diğer ifadeyle buradaki Tanrı, İslam dininde kendisine inanılan alim-i mutlak ve kadir-i mutlak tek olan Tanrı'dır. Dolayısıyla Tanrı kavramına referansla Allah ismi kullanılacaktır. Allah, İlah kelimesinden türemiş olup "tapınılan, yüceliğinin karşısında hayrete düşülen, gönülden bağlanılıp sığınılan" anlamlarını içermektedir (Topaloğlu, 2006). Başka bir ifadeyle Allah kâinatta var olan her şeyi yaratan, koruyan, tek ve yüce varlıktır (TDK, 2018). Sinanoğlu (2005) Allah'ın gerçek özünün kavranmasının imkânsız olduğuna değinmiş̧ir. Çünkü sonlu bir varlık olan insanların, sonsuz olan, gözle görülmeyen ve kainattaki hiçbir şeye benzemeyen bir "Yüce Varlık"ı kavraması mümkün gözükmemektedir. Dolayısıyla, Yaratıcı hakkında söylenen, düşünülen ve zihinde canlandırılan her şey O'nu tam anlamıyla yansıtmamaktadır. Allah, her ne kadar bilimsel yöntemlerle kavranan bir varlık değilse de tamamen bilinmez de değildir. Evren onun varlığına işaret eden delillerle doludur (Bilgin, 1986). Bu bağlamda Grom (1981) bireylerin Tanrı’ya ilişkin bilgilerinin; ebeveyn ilişkileri, diğer kişilerle ilişkiler, benliğe ilişkin duygular, Yaratıcı hakkında öğrenilenler, dini-kutsal metinlere ilişkin düşünceler ve Yaratıcı ile ilişki gibi faktörlerle şekillendiğini belirtmektedir. Bu bilgiye bakılarak bireylerin Tanrı'ya ilişkin tasavvurları kutsal kitaplar, yaşanılan sosyal ortam ve bireyin alg1 ve tecrübeleriyle geliştiği söylenebilir.

Çalışmanın odağında yer alan kavramlar hakkındaki bilgilerin aktarılmasından sonra Tanrı tasavvurları hakkındaki yaklaşımlardan bahsetmek araştırmamızın anlaşılmasına yardımcı olacaktır. Öncelikle ifade edilmelidir ki bireyin oluşturduğu Tanrı tasavvuru onun içerisinde bulunduğu gerçeklikten bağımsız değil bilakis bütünüyle bu gerçekliğin içerisindedir. Dolayısıyla sadece psikoloji alanında değil teoloji, antropoloji, sosyoloji ve felsefe gibi disiplinlerde de bireylerin Tanrı tasavvurunun gelişimine ilişkin yaklaşımlar geliştirilmiştir.

Tanrı tasavvurunun kökenine dair en meşhur yaklaşım Sigmund Freud'un geliştirdiği psikanalitik yaklaşımdır. Psikanalitik yaklaşıma göre Tanrı tasavvuru, çocukların ilk tasavvurlarından olan babaya ait tasarımların zihinsel bir yansımasıdır (Freud, 1927). Başka bir ifadeyle Tanrı, temelde yüceltilmiş bir babadan başka bir şey değildir (Freud, 1918). Çocuğun Tanrı-Baba kavramı, büyük bir olasılıkla kendi babasının ya da baba yerine koyduğu insanın kişiliğinin etkisinde kalacaktır (Arthur, 1979).

Psikanalitik yaklaşımdan sonra Tanrı tasavvurunun kökeni hakkındaki en dikkat çekici yaklaşımı Durkheim'ın oluşturduğu söylenebilir. Ona göre din toplumsal hayatın yüceltilen yönlerini temsil eden totemlerin oluşturulmasıyla var olmuştur. Bir diğer deyişle kutsiyet atfedilmiş her totem aslında toplumda kabul görmüş ve takdir 
edilmiş davranışı temsil etmektedir (Ritzer, 2014). Yani oluşturulan her totem aslında kolektif bilinçaltının yansımalarından ibarettir. Bu anlamda her toplum kendi Tanrı'sını kendi yaratmıştır. Dolayısıyla Durkheim'e göre Tanrı tasavvurunun oluşumu tamamen toplumsal bir olgudur.

Tanrı tasavvurunun kökenine dair psikoloji dışındaki disiplinlerde de yaklaşımlar geliştirilmekle birlikte Tanrı tasavvurunun gelişimine dair yaklaşımlar psikoloji disiplinin dışına çıkmamıştır. Tanrı tasavvurunun gelişimi hakkındaki yaklaşımlardan ilki Bağlanma Kuramı'dır. Bu yaklaşıma göre Tanrı tehlikelerden koruyan, bireyin kendini güvende hissetmesini sağlayan kusursuz ebeveyne benzediği için ideal bir bağlanma figürüdür (Kirkpatrick, 1992). Bu kurama göre ilk bağlanma figürü Tanrı tasavvuru oluşmasında önemli derecede etkiye sahiptir. Diğer bir ifadeyle Tanrı tasavvuru Freud'un savunduğu gibi babaya ilişkin tasavvurların yansımasından ibaret değildir. Çünkü Tanrı tasavvurunda baba imajı kadar anne imajı da ön planda olmaktadır. Yani Freud'un savunduğu "Tanrı yüceltilmiş bir baba figürü” yerine "Tanrı yüceltilmiş bir bağlanma figürü” görüşü hakimdir (Kirkpatrick, 1992).

Tanrı tasavvurunun gelişimi hakkındaki bir diğer yaklaşım ilişki kavramı üzerine odaklanan Nesne İlişkileri Kuramı'dır. Bu kuramda din ilişkisel bir süreç olarak görülmektedir (St. Clair, 2004). Bu kurama göre Tanrı tasavvuru bireyin geçmişteki ilişkilerine göre şekillenir, burada bireylerin çocukluk yıllarına ait deneyimleri ön plana çıkmaktadır (Ruchgy, 2004). Bu nedenle kuram; bireyin Tanrı ile ilişkisindeki sevgi, suçluluk, korku vb. gibi durumlar üzerine çalışmalar gerçekleştirmektedir (St. Clair, 2004). Bireylerin Tanrı ile ilişkilerindeki sevgi ve korku duygusu oluşumu aile bağlamında gerçekleştiği savunulmaktadır. Ancak Rizzuto (1973) Tanrı tasavvurunun bileşenlerinin sadece bireyin anne ve babasının tasavvurlarından oluşmadığı, diğer birçok kaynağın da bu tasarımın şekillenmesinde rol oynadığı sonucuna ulaşmıştır.

Bir diğer yaklaşım Erikson'un Sosyal Bilişsel Kuramı'na göre, temel güvene karşı güvensizlik olarak adlandırılan 0-1 yaşları aralığında çocuğa bakımla verilen güven, onda daha sonra gelişecek olan dindarlığın oldukça önemli bir konumundadır (Corvelyn ve Luyten, 2005). Ayrıca bu kuramda çocukların dini inancı öğrenebilmeleri için kendilerine rol model olacak yetişkinlere ihtiyaç duymaktadır (Gürses ve Kılavuz, 2011).

Bilişsel Kuramların en önemli temsilcilerinden biri olan Piaget, Bilişsel Gelişim Teorisi içindeki dört dönemin ilk ikisi olan duyusal motor ve işlem öncesi dönemde insan biçimci olan (antropomorfik) ve somut özellikler gösteren Tanrı tasavvuru görüldüğünü savunmaktadır (Mehmedoğlu, 2007). Çocukların somut işlemler döneminde Allah'1 insan şeklinde, yani "sıradan bir insana benzeyen, bulutların üzerinde yaşayan, diğer insanlardan farksız" bir varlık olarak tasvir etmeleri Piaget'ye göre o yaş döneminin özelliklerindendir (Piaget, 2005; Barrett ve Richert, 2003). Ayrıca Piaget, kuramında yer alan animizm ve yapaycılığın (artificialism) çocuklarda Tanrı tahayyülünün gelişimine etkide bulunduğunu savunmuştur (Piaget, 2005). İşlem öncesi dönemin ilk yıllarında animizm etkisiyle çocuk canlı ve cansız nesneler arasındaki ayrımın farkında 
olmaz. Yaşın ilerlemesine paralel olarak animizmin yerini yavaş yavaş yapaycılık alır (Piaget, 2005). Doğadaki olayların insan eliyle yapıldığı anlamına gelen yapaycılıkta, çocuk güneşin insanlar veya (insan olan) Tanrı tarafından bir çakıl taşı veya bir kibritle yakıldığını düşünecektir (Piaget, 2005).

Çocuklarda Allah tahayyülünün gelişimi onların yaş dönemlerine göre farklılaşmaktadır (Harms, 1944; Vergote, 1978, Çetin, 1991; Yıldız ve Arık, 2012). Okul öncesi çağ çocuklarında dini gelişim (4-6 yaş) incelendiğinde; 3-4 yaş çocukları, benmerkezci bir dünyada yaşar, nesneleri başka perspektiflerden göremezler. Buna göre Allah başta yalnızca kendilerinin yaratıcısıdır. Allah ona anne, baba, kardeşler vermiş hayatta kalması için gerekli yiyecekler, içecekler hazırlamıştır. Kısaca Allah sürekli çocuğun kendisiyle birlikte bulunmaktadır (Hökelekli, 1998; Yavuzer, 2001). $\mathrm{Bu}$ çocukların ayrıntılı mantıksal çıkarsama yetenekleri yoktur. 4. ve 5. yaşlarda çocuklar Allah'la ilgili konularda daha fazla soru sorma eğilimindedirler. Çocukların dinsel düşüncelerinin temelinde Allah kavramı yer almaktadır (Yavuz, 1983). Ancak bu çocuklarda henüz soyut düşünme becerileri gelişmediği için Allah'1 gerçek vücudu ve insani duyguları olan birisi olarak düşünme eğilimindedirler (Sohn, 1985). Çocukların Allah ile ilgili kullandığı her niteliğin içerisinde, fiziksel unsurlardan ve duyular âleminden izler bulmak mümkündür (Öcal, 2004). Onların düşüncelerinde Allah bazen; babalarından, dedelerinden veya görüp tanıdıkları bütün insanlardan çok daha büyük bir insan gibi (Bovet, 1958) veya en uzun boylu ağaçtan ve en yüksek dağlardan da büyüktür. Bu durum, okul öncesi döneminde bulunan çocukların genel olarak Allah'ın büyüklüğünü anlatırken tanıdıkları ve bildikleri bazı insan veya diğer varlıkları ölçü aldıklarını göstermektedir (Öcal, 2004). Clavier'e (1962) göre de çocuklar 6 ve 7 yaşına geldiklerinde Tanrı tahayyülleri antropomorfik özellikler göstermektedir. Bu düşünceye göre Allah, terasları olan bir evde ikamet etmektedir, çiçekler toplamaktadır (Akt. Vergote, 1978). Harms (1944) ise 3-6 yaş arasındaki çocukların Tanrı tahayyülleri "peri masalı evresi" olarak tanımlamıştır. Bu evrede Allah, kral veya çocukların babası olarak görülmektedir (Altaş, 2000).

İlkokul çağında bulunan çocukların dini gelişimi (7-10 yaş) incelendiğinde, bu çocukların yaşamlarının pek çok alanında somut düşünce tarzı kendini göstermektedir. Çocuklar henüz soyut düşünme kabiliyeti bakımından fazla gelişmediğinden çevresindekileri göründükleri gibi algilama eğilimindedir (Harms 1944). Bu dönemde çocukların Tanrı tahayyülleri daha çok antropomorfik (insan biçimci) olup, Tanrı için fiziksel özelliklerden bahsedilmektedir ve insana ait özelliklerle düşünülen, somutlaştırılmış bir Tanrı hayal edilmektedir (Garrod ve ark., 1990). Yavuz'un (1977) araştırmasında 7-9 yaş çocuklarının, 10-11 yaş çocuklarına göre Tanrı'yı insana veya bir başka şeye benzetme eğiliminin daha fazla olduğu; Tanrıyı insana benzetenlerin daha çok "ulu kişi”, "yüce kişi” olarak düşündükleri sonucuna ulaşılmıştır. Harms (1974) ise 7-12 yaş arasını "gerçekçi evre" olarak tanımlamıştır. Bu evrede Tanrı tahayyülü daha gerçekçidir. Çocuklar kendi çevrelerindeki dini tecrübelerden kendi Tanrı fikirlerini üretmektedirler. Bazıları Tanrı'yı, yaşamlarında etki sahibi olan bir kişi olarak çizmişlerdir. İlkokul çağının sonlarına doğru (9-10 yaş) çocuklar Allah'ı insanlardan 
farklı biçimlerde hayal etmeye başlamaktadırlar. Allah'ın kudretinden bahsedilince, çevresindeki insanların (baba vb.) kriter alan çocuklar, çevresindeki insanların her şeye gücünün yetmediğini fark ederek Allah'1n insanlardan daha farklı ve üstün bir varlık olduğunu anlamaktadırlar (Öcal, 2004). Clavier'e göre bunun nedeni 9-11 yaş aralığında antropomorfizmin hafiflemesidir. Bu yaş aralığındaki çocuklar Allah’ı diğer insanlara benzemeyen, onlar gibi olmayan bir biçim olarak algılamaya başlamaktadırlar. O’nu, meleklerle birlikte egemenliğini süren, dokunmanın ihtimal dahilinde olmadığı biçimde tasarlamaktadırlar (Akt. Vergote, 1978). Son olarak 12 yaşlarına gelindiğinde ise çocuklarda somut Allah inancı tamamen kaybolup yerine manevi (soyut) bir Allah inancı yerleşmektedir (Vergote, 1978).

Çocuklarda Tanrı tahayyülünün araştırıldığı çalışmalarda, Tanrı'nın sembolle ifadesinde sembollerin farklılaşmasında genellikle çocukların yaşları (Ladd, Mc Intosh ve Spilka, 1998) ailelerinin bağlı bulunduğu dini inanış (Takriti, Barrett, BuchananBarrow, 2006) ve cinsiyet (Kohlberg ve Kramer, 1969; Heller, 1988; Kay ve Ray, 2004) gibi faktörlerin önemli olduğu görülmektedir. Çocukların yaş değişkenine göre Tanrı kavramına ilişkin algılarındaki değişiklikler araştırmada belirtilmiştir. Tanrı kavramının cinsiyet değişkeni ile ilişkisini inceleyen Kohlberg ve Kramer (1969) Tanrı kavramıyla ilgili, kız çocuklarının "şefkat, empati kurma ve rahat ettirme" gibi bakımla ve "güç" ile ilgili niteliklere yoğunlaştıkları, erkek çocuklarının ise, "adalet, dürüstlük ve kanunlar" gibi nitelikleri içeren sadece "güç" konularına odaklandıkları saptamışlardır. Kay ve Ray (2004) tarafından 4-11 yaş aralığındaki çocuklarla gerçekleştirilen bir diğer çalışmada ise kız çocukları Tanrı'yı gülümseyen, gökyüzünde asker üniforması giyen yaşlı adam ve güneş içerisinde bulunan melekler şeklinde resmetmişlerdir. Erkek çocuklar ise Tanrı'yı muazzam bir güç gösteren, yeryüzünde bulunan süper kahraman olarak resmetmişlerdir.

Çocukların içinde bulunduğu sosyal çevrenin Tanrı tahayyülüne etkisi inceleyen Vianello, Carrajo ve Lis (1978) araştırmalarında aileleriyle birlikte yaşayan çocukların yetiştirme yurtlarında kalan çocuklarla karşılaştırmasını yapmışlardır. Elde edilen sonuçlar göstermiştir ki yetiştirme yurtlarında kalan çocuklar baba, anne ve Allah kavramları hakkında çok az olumlu bir imaja sahiptirler. Bu da Allah fikrinin çocuğun içinde bulunduğu toplumun en küçük birimi olan aileden olumlu veya olumsuz yönden doğrudan etkilendiğinin göstergesidir (Vienello ve Kalevi, 2000). 


\section{Araştırmanın Amacı}

Araştırmanın amacı, 5-8 yaş arasındaki çocukların Allah tahayyülleri hakkında bilgi edinmektir. Bu amaca uygun bir şekilde aşağıdaki sorulara cevap aranmaya çalışılmıştır;

1. Okul öncesi dönem olan 5-6 yaş ile okul dönemi olan 7-8 yaş çocuklarının Allah tahayyülleri arasında bir farklılık var mıdır?

2. Okul öncesi dönem olan 5-6 yaş ile okul dönemi olan 7-8 yaş çocuklarının Allah tahayyüllerinde cinsiyetten kaynaklanan bir farklılık var mıdır?

\section{Yöntem}

\section{Araştırmanın Modeli}

Nitel araştırmalar, kişilerin deneyimlerini, duygu ve düşüncelerini daha iyi anlayabilmek için tercih edilen araştırmalardır (Ekiz, 2009). Okul öncesi ve ilkokul çocuklarının Allah tahayyüllerini derinlemesine incelemenin amaçlandığ araştırmada, nitel araştırma yöntemlerinden olan "Olgubilim (fenomenoloji)" deseni kullanılmıştır.

Olgubilim deseni farkında olduğumuz ancak derinlemesine ve ayrıntılı bir anlayışa sahip olmadığımız olgulara odaklanmaktadır. Olgular yaşadığımız dünyada olaylar, deneyimler, algılar, yönelimler, kavramlar ve durumlar gibi çeşitli biçimlerde karşımıza çıkabilmektedir. Ancak bu tanışıklık olguları tam olarak anladığımız manasına gelmez. Bize tümüyle yabancı olmayan, aynı zamanda da tam anlamını kavrayamadığımız olguları araştırmayı amaçlayan çalışmalar için olgubilim uygun bir araştırma zeminini oluşturur (Yıldırım ve Şimşek, 2013). Araştırmacı katılımcının kişisel (öznel) tecrübeleri ile ilgilenmekte, bireyin algılamaları ve olaylara yükledikleri anlamları incelemektedir. Fenomenoloji tanımlayıcı bir araştırmadır. Bu bağlamda genelleme yapmak değil, olguları tanımlamak önemlidir (Akturan ve Esen, 2008).

$\mathrm{Bu}$ araştırmada, "Allah tahayyülü” olgusu incelenmeye çalışılmıştır. Araştırma, konuya ilişkin ilgili literatürün taranması, görüşme sorularının oluşturulması, görüşmenin gerçekleştirilmesi ve verilerin değerlendirilmesi biçiminde yürütülmüştür.

\section{Çalışma Grubu}

Araştırma, İstanbul Fatih ilçesindeki iki devlet ilkokulunda yapılmıştır. Araştırmanın çalışma grubu, 50'si (25 kız, 25 erkek) 5-6 yaş okul öncesi öğrencisi, 50'si (25 kız, 25 erkek) 7-8 yaş okul dönemi öğrencisi olmak üzere toplam 100 öğrenciden oluşmaktadır. Araştırmada, amaçlı örnekleme yöntemlerinden kolay ulaşılabilir durum örneklemesi (convenience sampling) yöntemi kullanılmıştır. Öğrenciler gönüllülük esasına göre araştırmaya katılmışlardır. 


\section{Veri Toplama Aracı}

Araştırmada, amaç bireylere araştırma konusuyla ilgili sorular yönelterek kişinin öznel düşünce ve duygularını sistemli olarak öğrenmek, anlamak ve tanımlamak (Kvale, 1996) amaçlandığı için birebir görüşme yönteminden yararlanılmıştır. Lincoln ve Guba (1985), nitel çalışmalarda örneklem seçiminde olabildiğince en geniş miktarda bilgi sağlayacak kişilerin seçiminin gerekliliğine değinmişlerdir. Çalışmada derinlemesine araştırma yapabilmek için çalışmanın amacı bağlamında bilgi açısından zengin durumlar seçilmesi gerektiği için amaçlı örnekleme yönteminden yararlanılmıştır.

Öğrencilerle birebir görüşme yapılmıştır. Bu görüşmelerde çocuklara aşağıdaki sorular yöneltilmiştir.

1. Allah’1 tanıyor musunuz? Kimden öğrendiniz?

2. Allah sence nasildır?

3. Allah'ın hangi özelliklerini biliyorsunuz?

4. Allah'tan en çok neyi istersin?

\section{Verilerin Analizi}

Araştırmada toplanan verilerin derinlemesine analiz edilmesinin gerekliliği ve önceden belirgin olmayan temaların ve boyutların ortaya çıkarılmasına olanak tanıması (Yıldırım ve Şimşek, 2008) nedeniyle içerik analizi yöntemi kullanılmıştır. Çalışmadaki içerik analizi ham verinin kodlanması ve doküman içeriğindeki ilişkili veriler ile kategorilerin oluşturulmasını kapsamaktadır.

\section{Geçerlik ve Güvenirlik}

Nitel araştırmalarda geçerlik, araştırmacının araştırdığı olguyu, olduğu biçimiyle ve olabildiğince yansız gözlemesi anlamına gelmektedir (Yıldırım ve Şimşek, 2013). Güvenirlik ise, bir araştırmadan elde edilen sonuçların farklı araştırmacılar tarafından da elde edilmesi şeklinde yorumlanmıştır (Marvasti, 2004). Araştırmada geçerlik ve güvenirliği sağlamak amacıyla inandırıcılık, aktarılabilirlik, tutarlılık ve teyit edilebilirlik (Yıldırım ve Şimşek, 2013) gibi stratejilerden yararlanılmıştır.

Nitel araştırmalarda iç geçerlik araştırmacının gözlediğine inandığı veya algıladığını düşündüğü olgulara ilişkin yorumların gerçek durumu yansıtıp yansıtmadığını ifade etmektedir (Miles ve Huberman, 1994). Araştırmanın iç geçerliğini (inandırıcıllğıını) artırmak için alanyazın taraması yapılmış, konuyla ilgili kavramsal bir çerçeve çizilerek görüşme soruları geliştirilmiştir. Yapılan veri analizinde temalar, ilgili kavramları içine alacak ve ilgisiz kavramları dışarıda bırakacak şekilde belirlenmeye ve temalar arası 
ilişkiler kontrol edilerek bir bütünlük oluşturulmaya çalışılmıştır. Görüşmeler kurum yönetiminin izniyle ve gönüllü öğrencilerle gerçekleştirilmiş, samimi bir ortamda karşılıklı güvenin oluşmasına gayret edilmiş, böylece verilen cevapların samimi ve gerçek verileri yansıtmasına çalışılmıştır. Araştırmada elde edilen bulgular eleştirel bir gözle sorgulanmış ve kuramsal çerçeveyle uyumluluk gösterdiği saptanmıştır. Araştırmanın dış geçerliği araştırma sonuçlarının genellenebilir olmasını ifade eden kavramdır. Araştırmanın dış geçerliğini arttırmak için tüm aşamalar ayrıntılı bir şekilde açıklanmaya çalışılmıştır. Ayrıca, araştırmanın modeli, araştırmanın yapıldı̆̆ı yer ve durum, çalışma grubu, verilerin toplanması, veri toplama araçları, verilerin analizi ve yorumlanması ayrıntılı bir biçimde tanımlanmıştır.

Araştırmanın iç güvenirliğini (tutarlığını) artırmak için elde edilen bulgular yorum yapılmadan aktarılmıştır. Ayrıca elde edilen veriler, bir uzmanla karşılıklı değerlendirilerek tutarlılığı karşılaştırılmıştır. Araştırmanın dış güvenirliğini (teyit edilebilirliğini) artırmak için süreçte yapılanlar araştırmacı tarafından ayrıntılı bir biçimde tanımlamıştır. Ayrıca elde edilen ham veriler ve kodlamalar araştırmacı tarafindan muhafaza edilmektedir.

\section{Bulgular}

Araştırmanın bu bölümünde, okul öncesi çağındaki 5-6 yaş çocukları ile okul çağındaki 7-8 yaş çocuklarının Allah tahayyülleriyle ilgili bilgi edinmek amacıyla yapılan yüz yüze görüşmelerden toplanan bulgulara yer verilmiştir.

Yapılan görüşme sonucunda çocuklara Allah'1 tanıyor musun? sorusu yöneltilmiş çocuklardan alınan cevapların analizine Tablo 1'de yer verilmiştir.

Tablo 1

Allah'ı tanıyor musun? sorusuna ilişkin veriler

\begin{tabular}{clcccc}
\hline Yaş & $\begin{array}{l}\text { Allah'1 } \\
\text { tanıma }\end{array}$ & $\mathbf{f}$ & $\mathbf{K i z}$ & \multicolumn{2}{c}{ Erkek } \\
$\mathbf{5}$ & Evet & 23 & 92 & 22 & $\mathbf{f}$ \\
& Hayır & 2 & 8 & 3 & 12 \\
\hline $\mathbf{6}$ & Evet & 19 & 76 & 25 & 100 \\
& Hayır & 6 & 24 & 0 & 0 \\
\hline $\mathbf{7}$ & Evet & 20 & 80 & 21 & 84 \\
& Hayır & 5 & 20 & 4 & 16 \\
\hline $\mathbf{8}$ & Evet & 25 & 100 & 25 & 100 \\
& Hayır & 0 & 0 & 0 & 0 \\
\hline
\end{tabular}


Tablo 1 incelendiğinde, 5 yaşında bulunan kız çocukların \% 92'si Allah'ı tanıdığını ifade ederken aynı yaş grubu erkek çocuklarında bu oran \% 88 olarak görülmektedir. 6 yaş çocuklarının Allah'ı tanıma oranlarına bakıldığında kız çocukların Allah'ı tanıma oranları \% 76 olarak gözlemlenirken erkek çocuklarında bu oran \% 100 olarak görülmektedir. 7 yaş kız çocuklarının \% 80’i Allah’ı tanıdığını ifade ederken, erkek çocuklarında bu oran \% 84'tür. 8 yaşındaki çocukların Allah'ı tanıma oranlarında ise kız ve erkek çocukların tümünün \% 100 Allah’ı tanıdığını ifade ettiği görülmektedir. Tablo 1'deki bilgilere bakılarak çocukların yaş artışına bağlı olarak Allah'ı tanıma oranlarında belirgin bir artış görülmezken yalnızca 8 yaşındaki çocukların tümünün Allah’ı tanıdığını ifade etmesi üzerine belirgin bir artış olduğu gözlenmiştir.

Allah tahayyülleri hakkında bilgi edinmek amacıyla görüşme yapılan 5-8 yaş aralığındaki çocuklara Allah'ı kimden öğrendikleri sorusu yöneltilmiş, alınan cevapların analizine Tablo 2'de yer verilmiştir.

Tablo 2

Allah'ı kimden öğrendin? sorusuna ilişkin veriler

\begin{tabular}{|c|c|c|c|c|c|c|}
\hline \multirow[t]{2}{*}{ Yaş } & \multirow{2}{*}{$\begin{array}{l}\text { Allah'ı } \\
\text { kimden } \\
\text { öğrendiği }\end{array}$} & \multicolumn{2}{|c|}{ Kız } & \multirow{2}{*}{$\begin{array}{l}\text { Allah'ı } \\
\text { kimden } \\
\text { öğrendiği }\end{array}$} & \multicolumn{2}{|c|}{ Erkek } \\
\hline & & f & $\%$ & & $\mathbf{F}$ & $\%$ \\
\hline \multirow{5}{*}{5} & Anne & 18 & 79 & Anne & 7 & 32 \\
\hline & Baba & 2 & 9 & Baba & 12 & 55 \\
\hline & Öğretmen & 1 & 4 & Ağabey & 1 & 4 \\
\hline & Anneanne & 1 & 4 & Babaanne & 1 & 4 \\
\hline & Babaanne & 1 & 4 & Teyze & 1 & 4 \\
\hline \multirow{6}{*}{6} & Anne & 9 & 47 & Anne & 15 & 60 \\
\hline & Baba & 6 & 32 & Baba & 7 & 28 \\
\hline & \multirow{2}{*}{$\begin{array}{l}\text { Cami Kuran } \\
\text { kursu }\end{array}$} & 1 & 5 & Ağabey & 1 & 4 \\
\hline & & 1 & 5 & Dede & 1 & 4 \\
\hline & Anneanne & & & & & \\
\hline & Babaanne & 2 & 11 & Hala & 1 & 4 \\
\hline
\end{tabular}




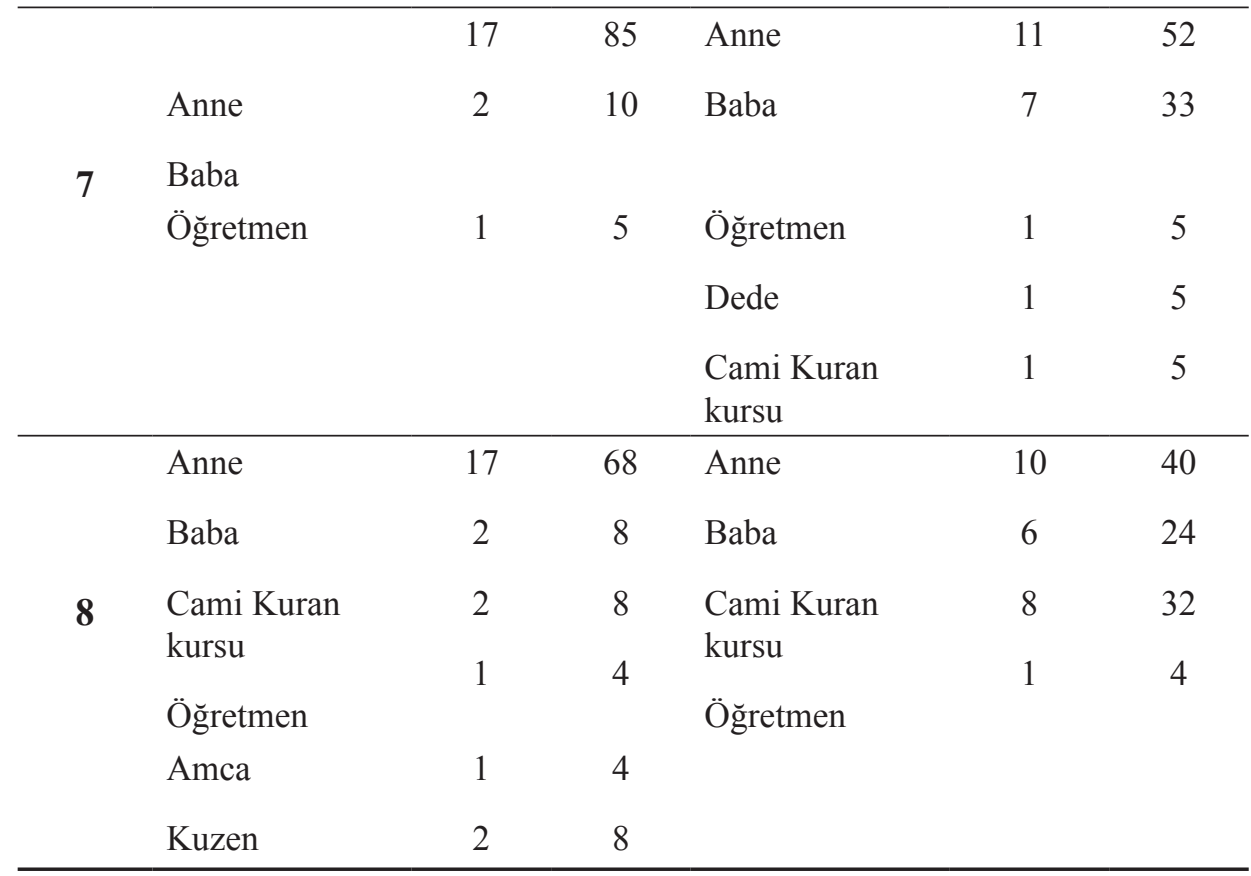

Tablo 2 incelendiğinde 5 yaşındaki kız çocukların \% 79'u Allah'ı annelerinden öğrendiklerini ifade ederken, \% 9'u Allah'ı babalarından, \% 4'ü ise öğretmenlerinden öğrendiklerini ifade etmişlerdir. 5 yaşındaki erkek öğrencilerin \% 60’ 1 kız öğrencilerden farklı olarak Allah'1 babalarından öğrendiklerini belirtirken, \% 32'si annelerinden öğrendiğini ifade etmiştir. 6 yaşındaki kız çocukların \% 47'si Allah'ı annelerinden öğrendiğini ifade ederken, \% 32'si babalarından öğrendiğini belirtmiştir. Aynı yaş grubu erkek çocukların \% 60’ı Allah’ı annelerinden, \% 28'i babalarından öğrendiğini belirtmiştir. 7 yaşındaki çocukların cevapları incelendiğinde, kız çocukların \% 85'i Allah'1 annelerinden öğrendiğini ifade ederken, \% 32'si babalarından öğrendiğini ifade etmiştir. Aynı yaş grubu erkek çocukların \% 52'si Allah’ı annelerinden öğrendiğini belirtirken, \% 33'ü babalarından öğrendiğini belirtmiştir. Bu verilere bakılarak, 6 ve 7 yaşındaki çocukların Allah'ı öğrendikleri kaynak çoğunlukla çocukların annesi olurken, çocukların babaları ise en çok belirtilen ikinci kaynak olmaktadır. 8 yaşındaki çocukların Allah'1 kimden öğrendin sorusuna verdikleri yanıtlar incelendiğinde kız çocuklarının $\%$ 68'i annelerinden, \% 8'i babalarından ve Kuran kurslarından öğrendiklerini belirtmişlerdir. 8 yaşındaki erkek çocukların ise \% 40’1 Allah’1 annelerinden, \% 32'si Kuran kurslarından, \% 24'ünün ise babalarından öğrendiği görülmektedir. Bu bilgiye bakıldığında 8 yaş çocuklarının da diğer yaş dönemlerinde olduğu gibi Allah'ı çoğunlukla annelerinden öğrendiği görülürken, çocukların Allah’1 öğrendiği ikinci kaynak Kuran kursları olmaktadır.

Allah tahayyülleri hakkında bilgi edinmek amacıyla görüşme yapılan 5-8 yaş aralığındaki çocuklara Allah sence nasıldır? sorusu yöneltilmiş, alınan cevapların analizine Tablo 3'de yer verilmiştir. 
Tablo 3

Allah sence nasıldır? sorusuna ilişkin veriler

\begin{tabular}{|c|c|c|c|c|}
\hline \multirow[t]{2}{*}{ Yaş } & \multirow[t]{2}{*}{ Allah sence nasıldır? } & \multicolumn{2}{|c|}{ Kız } & \multirow{2}{*}{$\begin{array}{l}\text { Allah sence } \\
\text { nasiddır? }\end{array}$} \\
\hline & & f & $\%$ & \\
\hline \multirow{13}{*}{5} & İnsana benziyor & 9 & 36 & Gökyüzünde \\
\hline & Gökyüzünde & 2 & 8 & İnsana benziyor \\
\hline & Meleğe benziyor & 1 & 4 & Mavi renkli canavar \\
\hline & Bulut & 1 & 4 & Görünmüyor \\
\hline & Bembeyaz beşgen şeklinde & 1 & 4 & Sihirli bir şey \\
\hline & Güzel bir prens & 1 & 4 & Camiye benziyor \\
\hline & Saçları sarı bir insan & 1 & 4 & $\begin{array}{l}\text { Çok büyük çok } \\
\text { güçlü deve benziyor }\end{array}$ \\
\hline & Çok büyük bir erkek & 1 & 4 & Ayıcı̆̆a benziyor \\
\hline & Gökyüzünde tatlı bir şey & 1 & 4 & Babaya benziyor \\
\hline & Düşünmedim & 1 & 4 & Herkese şeker verir \\
\hline & Bilmiyorum & 6 & 24 & $\begin{array}{l}\text { İyi ve güzel birisi } \\
\text { olabilir }\end{array}$ \\
\hline & & & & Bilmiyorum \\
\hline & & & & $\begin{array}{l}\text { Cami hocası gibi } \\
\text { cübbeli ve kasketli } \\
\text { bir şey }\end{array}$ \\
\hline \multirow{9}{*}{6} & İyidir, güzeldir & 2 & 8 & Akıllı olabilir \\
\hline & Her yerdedir çok severim & 1 & 4 & $\begin{array}{l}\text { Güzel oyuncak } \\
\text { adam gibi }\end{array}$ \\
\hline & Çok büyük & 3 & 12 & $\begin{array}{l}\text { Elleri ayakları } \\
\text { olmayan bulutların } \\
\text { arasında bir şey }\end{array}$ \\
\hline & $\begin{array}{l}\text { Büyük kolları ve gözleri olan } \\
\text { bir şey }\end{array}$ & 1 & 4 & $\begin{array}{l}\text { Yüzü ince kafaya } \\
\text { benziyor, parmakları } \\
\text { kocaman }\end{array}$ \\
\hline & Atatürk gibi, sadece yüzü var & 1 & 4 & İyidir görünmüyor \\
\hline & Küçük kuşa benziyor & 1 & 4 & $\begin{array}{l}\text { İyi bir şey Atatürk'e } \\
\text { benziyor }\end{array}$ \\
\hline & $\begin{array}{l}\text { Büyük kırmızı pembe binaya } \\
\text { benziyor }\end{array}$ & 1 & 4 & Hayal etmedim \\
\hline & Güzel ve büyük bir şey & 1 & 4 & Bilmiyorum \\
\hline & Sihirli sopası olan peri & 3 & 12 & $\begin{array}{l}\text { İçi çok güzel, } \\
\text { bilmiyorum }\end{array}$ \\
\hline
\end{tabular}




\begin{tabular}{|c|c|c|c|c|}
\hline & İnsana benziyor & 1 & 4 & Kara benziyor \\
\hline & Bilmiyorum & 10 & 40 & Büyük mavi kaya \\
\hline & & & & Gökyüzünde \\
\hline & & & & Güneşe benziyor \\
\hline & & & & $\begin{array}{l}\text { Çok karışık güzel } \\
\text { bir şey }\end{array}$ \\
\hline & & & & $\begin{array}{l}\text { Sicak ve büyük } \\
\text { güçlü adam } \\
\text { İyidir }\end{array}$ \\
\hline \multirow{18}{*}{7} & Büyük bir şey & 2 & 8 & Büsbüyüktür \\
\hline & İyidir & 4 & 16 & İyidir \\
\hline & Hiç görmedim bilmiyorum & 1 & 4 & Gençtir \\
\hline & Çok büyük & 1 & 4 & Güzeldir, iyidir \\
\hline & İyi kalplidir & 2 & 8 & $\begin{array}{l}\text { İyi kalpli, } \\
\text { arkadaşlarına iyi } \\
\text { davranıyor }\end{array}$ \\
\hline & Bize benziyor, orta boylu & 1 & 4 & Yaşlı sakallı erkek \\
\hline & Çok iyi & 1 & 4 & $\begin{array}{l}\text { İyi birisi, bize } \\
\text { benziyor, bizden } \\
\text { güzel }\end{array}$ \\
\hline & Gökyüzünde olan biri & 1 & 4 & Her şekle girebilir \\
\hline & Beyaz dumana benziyor & 2 & 8 & Kalbe benziyor \\
\hline & $\begin{array}{l}\text { Gökyüzünde yaşıyor, cinsiyeti } \\
\text { yok }\end{array}$ & 1 & 4 & Büyük bir bulut \\
\hline & Hiçbir şeye benzemiyor & 1 & 4 & Abime benziyor \\
\hline & $\begin{array}{l}\text { Beyaz renkte gökyüzünde } \\
\text { birisi }\end{array}$ & 1 & 4 & Gökyüzünde yaşıyor \\
\hline & Ceylanın daha güzeli & 1 & 4 & Bilmiyorum \\
\hline & Bilmiyorum & 6 & 24 & \\
\hline & Benzetemiyor & 4 & 16 & $\begin{array}{l}\text { Göremediğimiz } \\
\text { büyük kara benziyor }\end{array}$ \\
\hline & $\begin{array}{l}\text { Beyaz yuvarlak bir şeye } \\
\text { benziyor }\end{array}$ & 1 & 4 & Benzetemiyor \\
\hline & $\begin{array}{l}\text { Bize benzemiyor, kısa kol } \\
\text { entari giyen bir şey }\end{array}$ & 1 & 4 & $\begin{array}{l}\text { Sakallı insana } \\
\text { benziyor }\end{array}$ \\
\hline & Görünmez & 1 & 4 & $\begin{array}{l}\text { İyi bir insana } \\
\text { benziyor }\end{array}$ \\
\hline
\end{tabular}




\begin{tabular}{|c|c|c|c|}
\hline Gökyüzündeki bir şey & 3 & 12 & $\begin{array}{l}\text { Büyük bir üçgene } \\
\text { benziyor }\end{array}$ \\
\hline Büyük yuvarlak mavi bir şey & 1 & 4 & $\begin{array}{l}\text { Büyük bacakları } \\
\text { ve elbisesi olan } \\
\text { görünmeyen bir şey }\end{array}$ \\
\hline $\begin{array}{l}\text { İyi birisi, bizden güzel, bize } \\
\text { benzemiyor }\end{array}$ & 1 & 4 & $\begin{array}{l}\text { Büyük mavi kitap } \\
\text { gibi }\end{array}$ \\
\hline $\begin{array}{l}\text { Her tarafı nurla kaplı, } \\
\text { bembeyaz şekilsiz bir şey }\end{array}$ & 1 & 4 & $\begin{array}{l}\text { Bembeyaz geline } \\
\text { benziyor }\end{array}$ \\
\hline $\begin{array}{l}\text { Kanatlı beyaz pembe elbiseli } \\
\text { meleğe benziyor }\end{array}$ & 1 & 4 & $\begin{array}{l}\text { Çok büyük, beyaz, } \\
\text { alevli gök taşı }\end{array}$ \\
\hline İnsana benziyor (Erkeğe) & 10 & 40 & \\
\hline $\begin{array}{l}\text { Mavi başörtülü mavi gözlü } \\
\text { bayan }\end{array}$ & 1 & 4 & \\
\hline
\end{tabular}

Tablo 3'e bakıldığında 5 yaşındaki kız çocukların \% 36'sı Allah'ın insana benzediğini ifade ederken, \% 24'ü Allah'ın nasıl olduğunu bilmediklerini ve \% 8'i gökyüzünde bulunduğunu belirtmiştir. Aynı yaş grubunda bulunan erkek çocukların \% 28'i insana benzediğini belirtirken, \% 20'si bilmediğini, \% 12'si ise Allah'ın görünmediğini vurgulamıştır. 6 yaşındaki çocukların Allah'ın nasıl olduğu ile ilgili yanıtlarına bakıldığında; kız çocukların \% 40’1 Allah'ın nasıl olduğunu bilmediğini, \% 12'si çok büyük oluğunu ve sihirli sopası olan periye benzediğini belirtirken, aynı yaş grubundaki erkek çocukların \% 16'sı bilmediğini, \% 12'si bunu daha önce hayal etmediğini ve görünmediğini, \% 8'i ise onun gökyüzünde bulunduğunu belirtmiştir. 7 yaş çocuklarının Allah hakkındaki tahayyüllerine bakıldığında kız çocukların \% 24'ü Allah'ın nasıl olduğunu bilmediğini belirtirken, \% 16'sı O'nun iyi olduğunu, \% 12'si onun gökyüzünde yaşadığını \% 8'i ise büyük ve iyi kalpli olduğuna değinmiştir. Erkek çocukların Allah tahayyüllerine bakıldığında ise çocukların \% 28'nin Allah'ın nasıl olduğunu bilmediği, \% 16'sı O'nun büsbüyük olduğunu, \% 12'sinin ise O'nun iyi olduğunu belirttikleri görülmektedir. 8 yaş kız çocuklarının ise \% 40’ı O’nun insana benzediğini belirtirken, \% 16'sı O'nun hiçbir şeye benzemediğini belirtmiş, \% 12'si ise gökyüzünde bulunan bir şey olduğuna değinmiştir. Aynı yaş grubundaki erkek çocuklarının yanıtlarına bakıldığında, çocukların \% 48'i Allah'ı sakallı bir insana benzetmiştir. Tablodaki bilgiler incelendiğinde 5 ve 8 yaşındaki çocuklarda Allah'1 insana benzetme eğiliminin bulunduğu görülürken, 6 ve 7 yaş civarındaki çocuklar Allah'ın nasıl olduğunu bilmediklerini ancak onun büyüklüğü ve iyiliği gibi özelliklerine değindikleri görülmektedir. 
Allah tahayyülleri hakkında bilgi edinmek amacıyla görüşme yapılan 5-8 yaş aralığındaki çocuklara Allah'ın özellikleri nasıldır? sorusu yöneltilmiş, alınan cevapların analizine Tablo 4'de yer verilmiştir.

Tablo 4

Allah'ın özellikleri nelerdir? sorusuna ilişkin veriler

\begin{tabular}{|c|c|c|c|c|}
\hline \multirow[t]{2}{*}{ Yaş } & \multirow[t]{2}{*}{ Allah'ın özellikleri nelerdir? } & \multicolumn{2}{|c|}{$\mathrm{K} 1 \mathrm{Z}$} & \multirow[t]{2}{*}{$\begin{array}{l}\text { Allah’ın özellikleri } \\
\text { nelerdir? }\end{array}$} \\
\hline & & f & $\%$ & \\
\hline \multirow{18}{*}{5} & Bilmiyor & 10 & 40 & Yaratma, koruma \\
\hline & Yaratma, kalbimizde & 1 & 4 & $\begin{array}{l}\text { Yakma elektriğe, } \\
\text { çarptırma, dövme }\end{array}$ \\
\hline & İstediklerimizi verir & 2 & 8 & Kötüleri cezalandırır \\
\hline & $\begin{array}{l}\text { Herkesi duyar ve görür, biz onu } \\
\text { göremeyiz }\end{array}$ & 1 & 4 & $\begin{array}{l}\text { İyileri ödüllendirir, } \\
\text { kötüleri cezalandırır }\end{array}$ \\
\hline & $\begin{array}{l}\text { Duaları kabul eder, istediğimizi } \\
\text { verir }\end{array}$ & 1 & 4 & $\begin{array}{l}\text { Bağışlama, } \\
\text { cezalandırma }\end{array}$ \\
\hline & Yaratma, koruma & 5 & 20 & $\begin{array}{l}\text { Yaratma istediğini } \\
\text { yapma }\end{array}$ \\
\hline & Kötüleri cezalandırır & 2 & 8 & Koruma \\
\hline & Görünmez & 1 & 4 & Yaratma, yardım etme \\
\hline & $\begin{array}{l}\text { Kötüleri cezalandırır, iyileri } \\
\text { ödüllendirir }\end{array}$ & 1 & 4 & $\begin{array}{l}\text { Yaratma, insanların } \\
\text { karnına bebek verme }\end{array}$ \\
\hline & Yaratma, güçlü olma & 1 & 4 & $\begin{array}{l}\text { Yaratma, günah } \\
\text { işleyince ceza veriyor }\end{array}$ \\
\hline & & & & Günahlarımızı siler \\
\hline & & & & $\begin{array}{l}\text { Herkesi sever, görür, } \\
\text { herkese yemek verir }\end{array}$ \\
\hline & & & & Bilmiyorum \\
\hline & & & & Görünmez \\
\hline & $\begin{array}{l}\text { İyileri cennete koyar, kötüleri } \\
\text { cezalandırır }\end{array}$ & 2 & 8 & $\begin{array}{l}\text { Yaratma, büyüktür, } \\
\text { cehenneme atar, kör } \\
\text { eder }\end{array}$ \\
\hline & Bizi korur & 1 & 4 & $\begin{array}{l}\text { Affetme, duaları kabul } \\
\text { etme }\end{array}$ \\
\hline & Oyuncak verir & 1 & 4 & Yaratma \\
\hline & Bizi duyabilir & 1 & 4 & $\begin{array}{l}\text { Ceza verir, akşamı } \\
\text { yapar, uyku verir }\end{array}$ \\
\hline
\end{tabular}




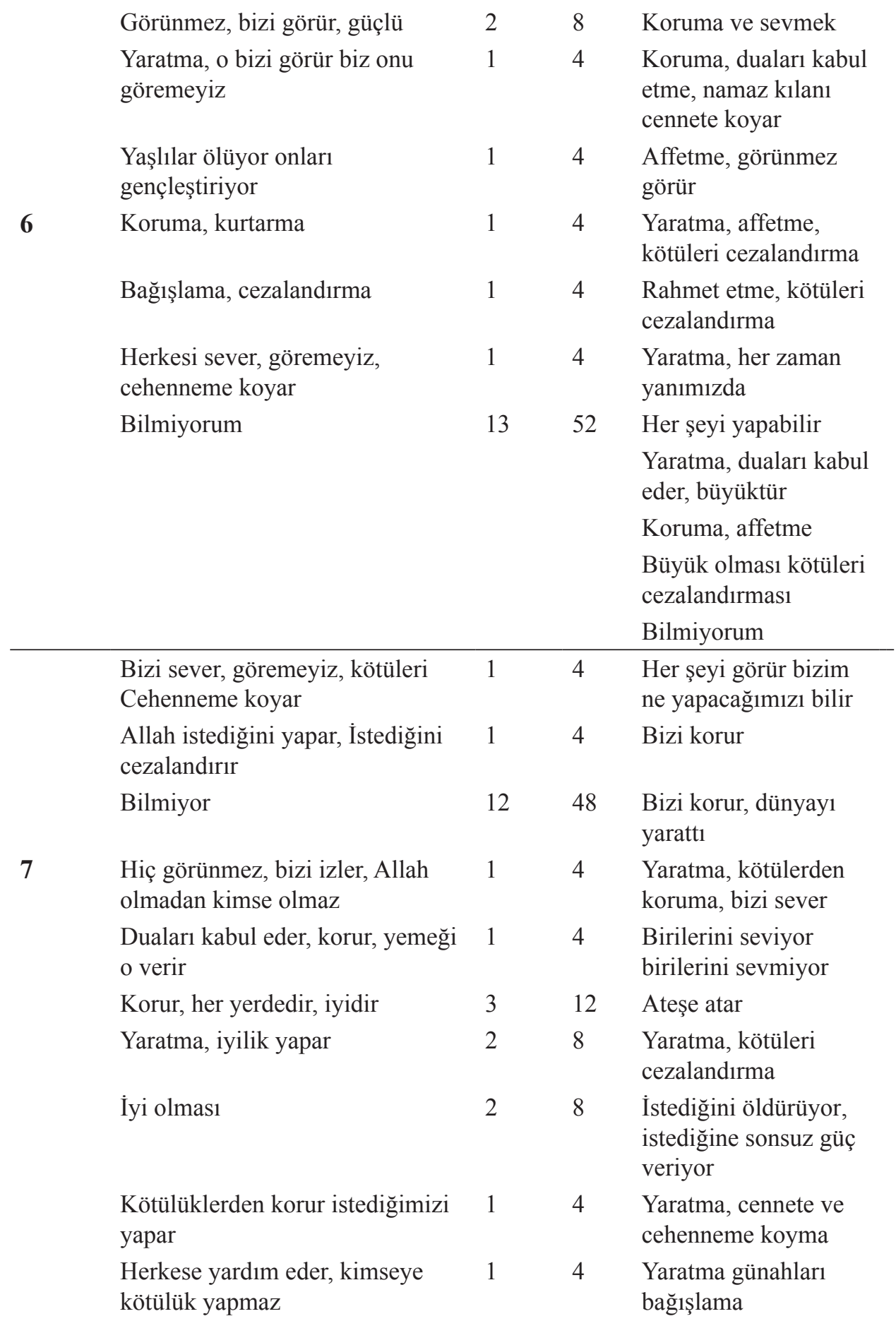


Duaları kabul eder, istediğimizi $1 \quad 4 \quad$ Affetme verir

Yaratma, uçma

Koruma, şeytanı

öldürür

Yaratma

İstediğini yapar

Bilmiyorum

Duaları kabul eder, her şeyi duyar, 6 iyileri cennete kötüleri cehenneme koyar, her yerdedir

Yardim etme

Yaratma, koruma, yağmur yağdırma

Yaratma, istediğimizi verme, kar 1 yağdırma

Biz ne istersek verir

Bize yardım eder

Yaratma, duaları kabul etme

8
Koruma, affetme, duaları kabul etme, her yerdedir

Yaratma, koruma, güçlüdür

Koruma, kötüleri cezalandırma, yaratma, bağışlama, esirgeme

Yaratma

Affetme, Kötüleri cezalandırma, iyileri ödüllendirme

Bilmiyorum
24

Affeder, yağmuru ve karı yağdırır

14 Bizi affeder

624 Kötüleri cezalandırır

4 Yaratma, yardim etme, cesaret verme

14 Yağmuru karı yağdırır, duaları kabul eder

14 Güneşi çıkarır

14 Yaratma, yağmuru karı yağdırma, yardım etme

28 Yaratma, geceyi gündüzü çıkartma

14 Yaratma, kötüleri cezalandırma, iyileri ödüllendirme

4 Yaratma, koruma

4 Bedeni yok görünmez

4 Kötüleri cezalandırır, görünmez

4 Bilmiyorum

Kötüleri

cezalandırma, koruma

Yaratma, koruma, duaları kabul etme 
Affetme, duaları kabul etme

Yaratma, zengin etme

Kötüleri cezalandırır, iyileri affeder

Büyüktür, affeder

Korur

Tablo 4 incelendiğinde 5 yaşındaki kız çocukların Allah'ın özelliklerinin neler olabileceğine ilişkin yanıtlarına bakıldığında; çocukların \% 40'1Allah'ın hangi özelliklere sahip olduğunu bilmediğini ifade ederken, \% 20'si O'nun yaratıp koruduğuna, \% 8'i ise O’nun kötüleri cezalandırdığına değinmiş̧ir. Aynı yaş grubundaki erkek çocukların \% 36'sı Allah'ın özelliklerini bilmediğine değinirken, \% 8'i O'nun yarattığını, kötüleri cezalandırdığını ve insanları koruduğunu belirmiştir. 6 yaş grubundaki çocukların cevapları incelendiğinde, kız çocukların \% 52'si Allah'ın özelliklerini bilmediğini, \% 8'i ise Allah'ın iyileri cennete attığını kötüleri cezalandırdığını, çok büyük ve güçlü olduğunu belirttiği görülmektedir. 6 yaşındaki erkek çocukların \% 28'i Allah'ın özelliklerini bilmediklerini ifade ederken, \% 20'si yaratma gücünün olduğuna değinmiştir. Ayrıca Allah'ın affedici, koruyucu olması ve kötüleri cezalandırması da değinilen kavramlar arasındadır. 7 yaşındaki kız çocuklarının Allah'ın özelliklerine ilişkin cevapları incelendiğinde; kız çocuklarının \% 48'i Allah'ın özelliklerini bilmediğini ifade ederken, \% 12'i O'nun koruyucu ve her yerde olduğunu belirtmiş, \% 8'i ise O'nun yarattı̆̆ını ve iyilik yaptığını belirtmiştir. Aynı yaş grubu erkek öğrencilerin cevaplarına bakıldığında; \% 36'sı O'nun özelliklerini bilmediğine değinirken, \% 8'i insanları koruduğuna ve dünyayı yarattı̆̆ına değinmiştir. Ayrıca çocuklar Allah'ın her şeyi görme, affetme ve kötüleri cehenneme atma gibi kavramlara da değindiği görülmektedir. 8 yaş çocukların cevaplarına bakıldığında; kız çocuklarının \% 24'ü Allah'ın duaları kabul ettiğini, iyileri cennete kötüleri cehenneme koyduğunu, O'nun yarattığını ve yağmur yağdırdığını belirtmiş, \% 8'i ise O'nun koruduğuna, affettiğine ve her yerde olduğuna değinmiştir. Aynı yaş grubu erkek çocuklarının yanıtları incelendiğinde; erkek çocuklarının \% 16'sı Allah'ın affediciliği ve duaları kabul ettiğine değinmiş, \% 8'i O'nun yarattığını, gece ve gündüzü oluşturduğunu ve görünmez olduğunu belirtmiştir. Ayrıca çocuklar Allah'ın yağmuru ve karı yağdırdığı, güneşi açtırdığı gibi doğa olaylarına ilişkin ifadelere de yer verdikleri görülmektedir. Bu bilgilere bakılarak 5, 6, 7 yaşındaki çocukların Allah'ın özelliklerinin neler olduğunu genel anlamda bilmedikleri ve Allah'ın özelliklerini genel olarak yaratma, koruma, kötüleri cezalandırma vb. ifadelerle belirttikleri görülmüş, 8 yaş çocuklarının ise büyük çoğunluğunun Allah'ın özellikleri hakkında fikir sahibi oldukları görülmektedir. Çocukların çok az bir kısmı (\% 4) Allah'ın özelliklerini bilmediğini ifade etmiştir. Ayrıca 8 yaş çocukları Allah'ın özelliklerini belirtirken yağmur ve kar yağdırma, gece ve gündüzü oluşturma, güneşi çıkarma gibi doğa olaylarından yararlandıkları gözlenmiştir. 
Allah tahayyülleri hakkında bilgi edinmek amacıyla görüşme yapılan 5-8 yaş aralığındaki çocuklara Allah'tan neler istedikleri sorusu yöneltilmiş, alınan cevapların analizine Tablo 5'de yer verilmiştir.

Tablo 5

Allah'tan neler istersin? sorusuna ilişkin veriler

\begin{tabular}{|c|c|c|c|c|c|c|}
\hline \multirow[t]{2}{*}{ Yaş } & \multirow[t]{2}{*}{ Allah'tan istekler } & \multicolumn{2}{|c|}{ Kiz } & & \multicolumn{2}{|c|}{ Erkek } \\
\hline & & $\mathbf{f}$ & $\%$ & & $\mathbf{f}$ & $\%$ \\
\hline \multirow{21}{*}{5} & Oyuncak bebek & 3 & 12 & & 4 & 16 \\
\hline & İstemiyorum & & & & & \\
\hline & Gökyüzünden oyuncak yağması & 1 & 4 & $\begin{array}{l}\text { Tavuklu } \\
\text { pilav, } \\
\text { şeker }\end{array}$ & 1 & 4 \\
\hline & Yapıştırıcı & 1 & 4 & Yemek & 2 & 8 \\
\hline & Anne ve babanın mutluluğu & 1 & 4 & & 2 & 8 \\
\hline & Kendine ait havuz & 1 & 4 & & 1 & 4 \\
\hline & Hemen yaz mevsiminin gelmesi & 1 & 4 & $\begin{array}{l}\text { Zengin } \\
\text { olmak }\end{array}$ & 1 & 4 \\
\hline & Güzel bir aile & 1 & 4 & Kar & 1 & 4 \\
\hline & Parasız çocuklara para vermesini & 1 & 4 & & 1 & 4 \\
\hline & Babamın biz para göndermesini & 1 & 4 & Bizi & 1 & 4 \\
\hline & Daha çok kar yağmasını & 2 & 8 & $\mathrm{~K} 1 \mathrm{z}$ & 1 & 4 \\
\hline & Allah’ın cinsiyetini öğrenmek & 1 & 4 & & 1 & 4 \\
\hline & Kardeşimin olması & 1 & 4 & $\begin{array}{c}\text { Tavuk } \\
\text { yemek }\end{array}$ & 1 & 4 \\
\hline & Yemek & 1 & 4 & Kek & 1 & 4 \\
\hline & Boya Kalemi & 1 & 4 & $\begin{array}{l}\text { Baba } \\
\text { olmak }\end{array}$ & 1 & 4 \\
\hline & Teyzemi isterim & 1 & 4 & $\begin{array}{l}\text { Polis } \\
\text { olmak }\end{array}$ & 1 & 4 \\
\hline & Oyuncak & 2 & 8 & Para & 1 & 4 \\
\hline & Herkesin iyi olmasını & 1 & 4 & Ailemi & 1 & 4 \\
\hline & Eğlence isterim & 1 & 4 & & 1 & 4 \\
\hline & & & & & 1 & 4 \\
\hline & & & & Evime & 1 & 4 \\
\hline & Dondurma & 1 & 4 & Bisiklet & 1 & 4 \\
\hline & Oyuncak bebek & 2 & 8 & Kek & 1 & 4 \\
\hline & Sinemaya gitmek & 1 & 4 & & 1 & 4 \\
\hline
\end{tabular}


Şeker çikolata

Barbie bebek

İstemiyor

Köpek

Kardeşimin annemi üzmemesini

Oyuncak gül

Kuş isterim

Yemek

6 At isterim

Oyuncak peri

Kız kardeşim olmasını

Büyük bir evde kendi kendine oynamak

Ailemi korumasını isterim

İstemeye korkuyorum

$\begin{array}{lllll}1 & 4 & \begin{array}{l}\text { Boya } \\ \text { kalemi }\end{array} & 1 & 4 \\ 1 & 4 & & 1 & 4 \\ 6 & 24 & \text { Beni } & 1 & 4 \\ 1 & 4 & \text { Kar } & 1 & 4 \\ & & \begin{array}{l}\text { yağsın } \\ \text { ve yaz } \\ \text { gelsin }\end{array} & & \\ & & & \end{array}$

1

1

14

$\begin{array}{lll}4 & \text { Sürpriz } & 1 \\ 4 & \text { Köpek } & 1 \\ 4 & \text { Bütün } & 1 \\ & \text { şehir } & \\ & \text { yalan } & \end{array}$

4

4

4

yalan

1

1

14

14

1

4

Süt

$\begin{array}{ll}2 & 8\end{array}$

4 Süt

14

14

14

14

$\begin{array}{lllll}1 & 4 & \text { Yüzme } & 1 & 4\end{array}$

havuzu

$\begin{array}{lllll}3 & 12 & \text { At } & 1 & 4\end{array}$

isterim

\begin{tabular}{|c|c|c|c|c|c|}
\hline & & & & 1 & 4 \\
\hline & & & & 1 & 4 \\
\hline & & & Annem & 1 & 4 \\
\hline & & & Yemek & 1 & 4 \\
\hline & & & & 2 & 8 \\
\hline & & & & 1 & 4 \\
\hline Ailemi korumasını isterim & 1 & 4 & & 3 & 12 \\
\hline Eski arkadaşlarımı görmek isterim & 1 & 4 & Babamı & 1 & 4 \\
\hline Elma & 1 & 4 & & 1 & 4 \\
\hline Barbie bebek & 1 & 4 & $\begin{array}{l}\text { Yemek } \\
\text { isterim }\end{array}$ & 1 & 4 \\
\hline Pilav & 1 & 4 & $\begin{array}{l}\text { Süt } \\
\text { isterim }\end{array}$ & 1 & 4 \\
\hline Yeni eve taşınmak & 2 & 8 & Seni & 1 & 4 \\
\hline Ev & 2 & 8 & $\begin{array}{l}\text { Babamı } \\
\text { isterim }\end{array}$ & 2 & 8 \\
\hline
\end{tabular}




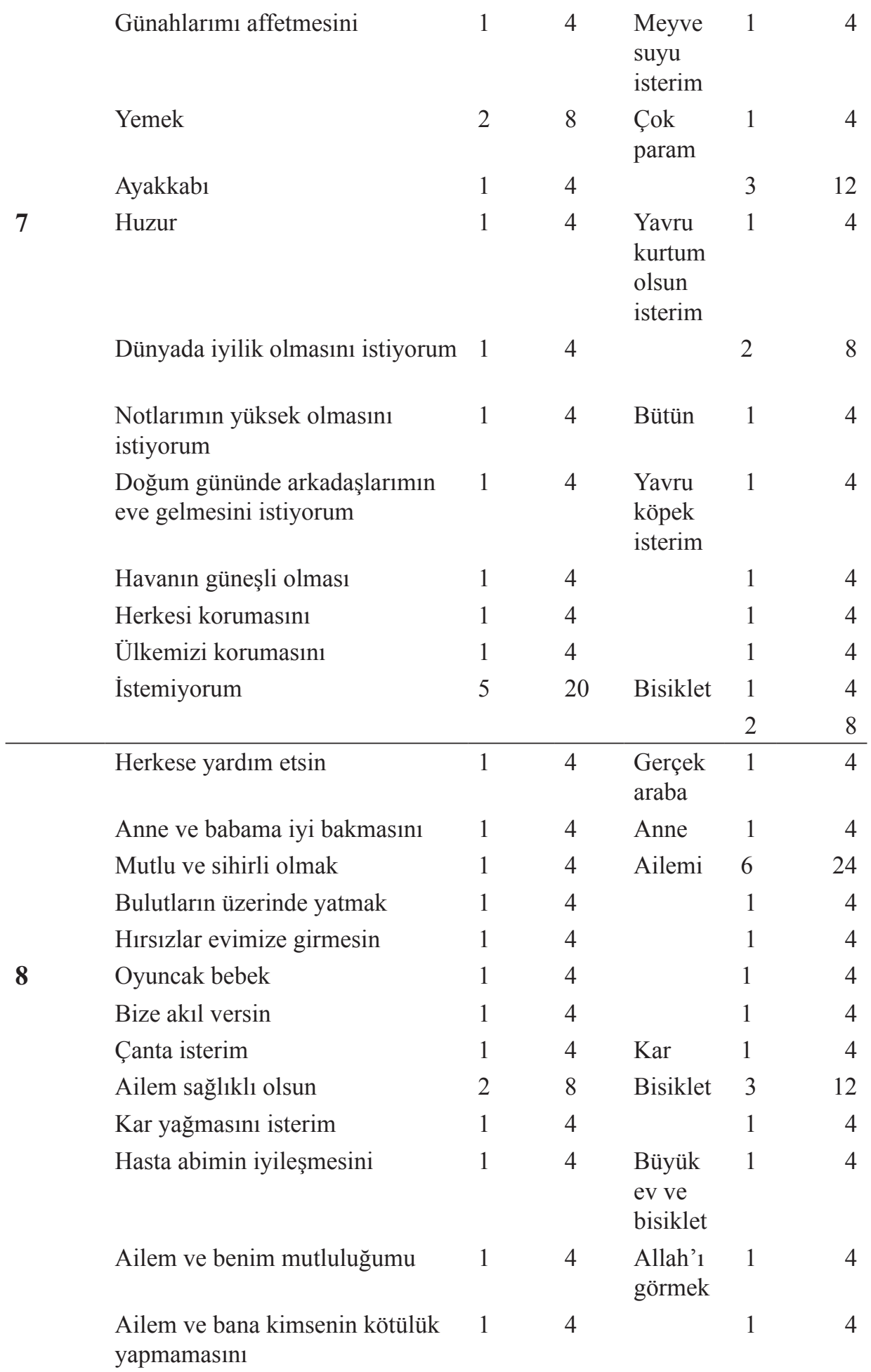




\begin{tabular}{|c|c|c|c|c|}
\hline Mutluluk isterim & 1 & 4 & & 1 \\
\hline Polis olmak isterim & 1 & 4 & & 2 \\
\hline Bisiklet & 2 & 8 & & 1 \\
\hline Bütün insanları korumasını & 1 & 4 & & 1 \\
\hline Ailemi korumasını & 4 & 16 & $\begin{array}{l}\text { Lüks } \\
\text { bir ev }\end{array}$ & 1 \\
\hline Herkesin iyi ve çalışkan olmasını & 1 & 4 & & \\
\hline İstemiyorum & 1 & 4 & & \\
\hline
\end{tabular}

Tablo 5'e bakıldığında, 5 yaşındaki kız çocuklarının Allah'tan isteklerine ilişkin ifadeleri incelendiğinde k1z çocuklarının \% 12'si oyuncak bebek istediğini ifade ederken \% 8'i kar yağmasını istediklerini belirtmiştir. Ayrıca çocukların ifadeleri incelendiğinde gökyüzünden oyuncak yağması, kendine ait havuzunun olması ve boya kalemi gibi isteklerinin de bulunduğu görülmektedir. Aynı yaş grubu erkek çocuklarının \% 16'sı Allah'tan istediği bir şey olmadığını belirtirken \% 8'i yemek, oyuncak araba gibi isteklerinin olduğunu ifade etmişlerdir. 6 yaş çocuklarının Allah’tan isteklerine ilişkin ifadelerine bakıldığında kız çocuklarının \% 24'ü Allah’tan bir şey istemediğini belirtirken, \% 12'si O’ndan bir şey istemeye korktuklarını ifade etmişstir. Bunlara ek olarak kız çocukları oyuncak bebek, köpek, at, dondurma vb. istekleri olduğuna da değinmişlerdir. Aynı yaş grubu erkek çocukların Allah’tan neler istediğine ilişkin ifadelerinde; çocukların \% 8'i bir şey istemediğini, oyuncak istediğini belirtirken \% 4'ü cennete gitmek, köpek, oyuncak, kek, büyümek vb. isteklerinin olduğunu belirtmiştir. 7 yaşındaki kız çocuklarının ifadelerine bakıldığında, çocukların \% 20'si Allah'tan bir şey istemediğini belirtirken, \% 8'i yeni eve taşınma, yemek gibi isteklerine değinmiş, \% 4'ü ise oyuncak, günahlarını affetmesini, notlarının yüksek olmasını, ailesini korumasını, ülkemizi korumasını vb. istekleri olduğunu belirtmiştir. Aynı yaş grubu erkek çocuklarının Allah’tan istekleri incelendiğinde; çocukların \% 12'si Allah'tan bir şey istemediğini, oyuncak istediğini belirtirken, \% 8'i babasını ve cennete girmek istediğini belirtmiştir. Ayrıca çocuklar bu isteklerinin yanı sıra Allah'ın insanları koruması, kötülüğün iyiliğe dönüşmesi, tüm Müslümanların günahlarını affetmesi, çok parası olması vb. istekleri de bulunmaktadır. 8 yaşındaki kız çocuklarının \% 16's1 Allah'ın ailesini korumasını, \% 8'i bisiklet ve ailesinin korunması, \%4'ü ise mutluluk, polis olmak, herkese yardım edilmesi, hasta abinin iyileşmesi vb. isteklerine değinmiştir. Aynı yaş grubu erkek çocuklarının \% 24'ü Allah'ın ailesini korumasını, $\%$ 12'si bisiklet, \% 8'i ise büyümek istediğini belirtmiştir. Ayrıca çocuklar cennete gitmek, anne babalarının ölmemesi, kimsenin ölmemesi, kıyamet gününün olmaması, dünyadaki savaşların bitmesi vb. istekleri de bulunmaktadır. 


\section{Tartışma ve Sonuç}

İnsanların inanma ihtiyaçları yaradılıştan gelmektedir. Bireylerin inançları Tanrı ekseninde şekillenmekte ve Tanrı tasavvuru çoğunlukla dini hayatın en merkezi kavramı olarak nitelendirilmektedir. Araştırmada bireylerin diğer varlıklarla olan ilişki biçimlerini etkileyen, temeli erken çocukluk döneminde atılan ve bireylerin yaşantılarında bu denli öneme sahip kavram olan Tanrı tahayyüllerinin okul öncesi ve ilkokul öğrencilerinde (5-8 yaş) incelenmesi amaçlanmıştır.

5-8 yaş aralığındaki çocukların Allah tahayyülleri hakkında bilgi edinmenin amaçlandığı çalışmada çocukların Allah'ı tanıyıp tanımadıkları incelenmiştir. Elde edilen verilere göre çocukların büyük çoğunluğu (\% 87) Allah'ı tanıdığını ifade ederken, az bir kısmı (\% 13) tanımadığını belirtmiştir. Çocukların Allah'ı tanıma oranları cinsiyete göre dağılımında; kız çocuklarının Allah'ı tanıma oranları yalnızca 5 yaş civarında erkeklerden fazla olduğu, diğer yaş dönemlerinde erkek çocukların kız çocuklarına oranla Allah'ı tanıma oranlarının daha yüksek olduğu saptanmıştır. Yaşla birlikte çocukların Allah'ı tanıma oranlarında belirgin bir artış görülmemektedir. Ancak 8 yaş çocuklarının tümünün Allah'ı tanıdıklarını belirttiği tespit edilmiştir. Çocuklarla yapılan görüşmelerde, Allah'ı tanımadığını ifade eden çocukların Allah'ı tanıdıkları fakat ifade edemedikleri de gözlenmiş̧ir. Çocuklara soru ilk sorulduğunda biraz tereddüt ettikleri fakat zamanla güven ilişkisi kurulduktan sonra kendilerini rahatça ifade edebildikleri gözlemlenmiştir.

Çocukların Allah'ı kimden öğrendiklerine ilişkin elde edilen verilere göre, çocukların büyük çoğunluğunun Allah'1 annelerinden öğrendikleri sonucuna ulaşılmıştır. Anne dışındaki diğer kaynak ise 5, 6, 7 yaş gruplarında baba olmaktadır. Bu sonuca paralel olarak Dickie ve arkadaşları (2006) gerçekleştirilen bir çalışmada ebeveynlerin özellikle annelerin, kız ve erkek çocuklarının dinî algılarını ve Tanrı tahayyüllerini etkiledikleri saptanmıştır. Rizzuto'ya (1979) göre çocuk Tanrı tahayyülünü tek başına değil, anne-baba, kilise, yetişkinlerin din hakkındaki konuşmalarıyla şekillenmektedir. Erikson'un sosyal bilişsel kuramında da çocuklar dini inancı öğrenebilmeleri için kendilerine rol model olacak yetişkinlere ihtiyaç duydukları belirtilmiştir (Gürses ve Kılavuz, 2011). Çocuklarda Allah tahayyülünün oluşmasında birinci dereceden annenin daha sonra babanın etkisi açık bir şekilde görülmektedir. Dickie ve arkadaşlarının (1997) bu konu üzerine yaptıkları bir diğer çalışmada aynı bulguya ulaşmışlar ve bu durumun zamanla tam tersine dönmesini çocuğun hangi ebeveyni güçlü ve merkezi gördükleri ile ilişkili olduğu kanaatine varmışlardır. Öğretmen, dede, anneanne/ babaanne ve büyük kardeş etkisi ise çok kısıtlı kalmaktadır. Bu sebeple ebeveynlerin çocuklarına din eğitimi verirken ve Allah'ı öğretirken kalıcı etkisi her zaman göz önünde bulundurulmalıdır. Nitekim Öcal'a (2004) göre anne ve babalara düşen görev ise çocuklardaki Tanrı tahayyülünün sağlıklı bir şekilde ve gelişim aşamalarına uygun olarak ortaya çıkmasına yardımcı olmaktır. Zira çocukların Tanrı tahayyülünün oluşumunda ailenin eğitim biçiminin yanısıra kendi Tanrı tahayyülleri de oldukça etkili olmaktadır (Hertel, 1995). Bu araştırmada 8 yaşındaki çocukların da Allah'ı çoğunlukla 
annelerinden öğrendiği sonucuna ulaşılmaktadır. Ancak 8 yaş çocuklarında Allah'ın öğrenildiği ikinci kaynak diğer yaş dönemlerinden farklı bir şekilde baba yerine Kuran kursları olarak saptanmıştır. Çocukların Allah'ı Kuran kursundan öğrenme oranı cinsiyete göre de farklılık göstermektedir. Erkek çocuklarının, Allah'1 Kuran kursundan öğrenme oranının, kız çocuklarına göre daha fazla olduğu saptanmıştır. 8 yaşındaki erkek çocukların cami Kuran kurslarına gönderilmesi yani yaş büyüdükçe ailenin, dini eğitim amaçlı kurumlardan yararlanması fakat aynı yaş grubundaki kız çocukların ise kurumlara gönderilmemesi dikkat çekmektedir.

Çocukların Allah'ın onlara göre nasıl olduğu sorusuna ilişkin elde edilen verilere göre 5 yaşındaki çocuklar genel anlamda Allah'ın insana benzediğini ifade etmişlerdir. Başka bir ifadeyle çocuklardaki Allah tahayyülü antropomorfik özellikler taşımaktadır. 5 yaş çocuklarının Allah’ı tanımlarken “Güzel bir prens, saçları sarı bir insan, çok büyük bir erkek, sakall Kuran okuyan biri, babaya benziyor, cami hocası gibi cübbeli ve kasketli bir şey" gibi ifadeler kullanması Allah'ın insana benzetilmesine örnek verilebilir. Lond, Elkind ve Spilka'ya (1967) göre de ilk çocuklukta Allah düşüncesi antropomorfisttir. Bu dönemde Allah insani vasıfların tümünü taşıyan, gökyüzünde yaşayan, düşmanları ve dostları olan yaşlı bir dede olarak tasavvur edilir. Bu sonuca paralel olarak Barnes tarafindan gerçekleştirilen Kaliforniyalı çocukların dini yaşantısının araştırıldığı çalışmada çocukların büyük bir bölümünün Allah’ı büyük ve çok iyi bir insan olarak tasavvur ettikleri görülmüştür. Bazı çocuklar ise Tanrıyı beyaz elbise giyen, aksakallı bir ihtiyar olarak tasvir etmişlerdir (Akt., Selçuk, 1990). Bovet'e (1958) göre 5 yaşındaki çocuklar henüz somut düşündüklerinden Allah'ı da somut varlık olarak algılarlar. Onların düşüncelerinde Allah tüm insanlardan çok daha büyük bir insan gibidir. Mehmedoğlu (1998) tarafindan gerçekleştirilen çocuklarda dini duygunun gelişiminin incelendiği çalışmada, 5-6 yaş grubu çocuklar tarafindan Allah doğal olarak insani vasıflarla tasavvur edilmektedir. Çocukların Allah ile ilgili kullandığı her sıfatın içerisinde, fiziksel unsurlardan ve duyular âleminden bir şeyler bulmak mümkündür.

Araştırmaya katılan 6 yaş çocukların Allah'ın nasıl olduğu ile ilgili elde edilen verilere bakıldığında; kız çocukları Allah'ın çok büyük olduğuna vurgu yaptıkları tespit edilmiştir. 6 yaşındaki kız çocuklarının Allah'ı tanımlarken "Çok büyük, büyük kollarl ve gözleri olan bir şey, büyük kirmızı pembe binaya benziyor, güzel ve büyük bir şey" gibi ifadeler kullanması Allah'ın büyüklüğüne yapılan vurguya örnek verilebilir. Öcal (2004) tarafından gerçekleştirilen çalışmada 6 yaşındaki kız ve erkek çocukların ifadelerinde "Allah çok büyük, beyaz sakallı, beyaz elbisesi ve beyaz şapkası var. Çok büyüktür. Allah büyüktür vb.” ifadeler Allah'ın büyüklüğüne vurgu yapıldığı görülmektedir. Aynı yaş grubundaki erkek çocuklarına bakıldığında; Allah'ı insana benzetme yerine farklı büyük ve iyilik özellikleri taşıyan nesne ve maddelere benzetildiği saptanmıştır. Bu araştırmada çocukların Allah'1 tanımlarken "Kara benziyor, Büyük mavi kaya, Gökyüzünde, Güneşe benziyor, Çok karışık güzel bir şey, Sıcak ve büyük güçlü adam" gibi ifadeler kullanması bu sonucu destekler niteliktedir. Leuba (1917) tarafından gerçekleştirilen çalışmada küçük çocukların Tanrı'yı 'ruha, 
buluta, ateş topuna' başka bir deyişle nesne ve maddelere benzettiklerini; çocukların üçte birinin de Tanrı'yı 'güçlü bir adam, bir insan ve yaratıcı' olarak tasvir ettiklerini saptanmıştır (Akt. Thackeray, 2000).

7 yaşındaki çocukların Allah'ın nasıl olduğuna ilişkin elde edilen verilere bakıldığında; kız çocukların Allah’ı iyi, gökyüzünde yaşayan, büyük ve iyi kalpli olarak tanımladığı tespit edilmiştir. Kız çocuklarının Allah'ı tanımlarken "Allah büyük bir şeydir. Çok büyük, iyidir, iyi kalplidir çok iyidir. Gökyüzünde olan biri, beyaz dumana benziyor, gökyüzünde yaşıyor cinsiyeti yok beyaz renkli biri." gibi kullandıkları ifadeler bu sonucu destekler niteliktedir. Allah'ın gökyüzünde yer almasına paralel olarak Mehmedoğlu (1998) tarafından gerçekleştirilen çalışmada çocuklara göre Allah gökyüzünde, bulutların üstünde, havada, uzayda (\% 57) gibi yukarıda bir yerlerde yaşadığı sonucuna ulaşılmıştır. Yavuz (1986) tarafindan gerçekleştirilen diğer bir çalışmada, Allah'ın nerede olduğu sorusuna ilişkin yanıtlar şu şekildedir; “Allah göktedir", “üstümüzde”, gökyüzünde", "havada", "nerede dersen, O oradadır", “gökyüzünün en yüksek katındadır”, "yücelerde”, "bulutları ötesinde”, “cennette”, "iyi kalpli insanların kalplerinde”, “O’nun nerede olduğu bilinemez”, “Allah göktedir”, “dünyadan çok yukarıdadır”, "her yerdedir” şeklindedir. Yavuz’a (1986) göre çocukların Tanrı'yı özellikle gökte, bulutların üstünde, yukarıda vb. olduğunu söylemesi, saygı gösterilmesi gereken ve yüce olan Tanrı'nın mekan seçimi için doğaldır. 7 yaşındaki erkek çocukların, Allah'ın nasıl olduğuna ilişkin elde edilen verilerde, Allah'ın iyi kalpli olduğu ve çok büyük olduğunu sonucuna ulaşılmıştır. Peker'e (1993) göre bu yaş döneminde Allah ile ilgili çocuğa verilen bilgiler ve eğitim çocuğun din duygusunun gelişiminde oldukça etkilidir. Diğer bir ifadeyle çocuğa bu yaşlarda "Allah yaramazlık yapanı yakar, cehennemine atar vb. sözlerle korkutulursa çocukta Allah korkusu; Allah kullarını sever, onlara her zora düştüklerinde yardım eder, iyiliklerde bulunur, cennete yollar vb. sözler çocukta Allah sevgisinin oluşumuna katkı sağlamaktadır (Ay, 1994; Tütüncü, 1987). Bu sonuca paralel olarak Nelsen ve Kroliczak (1984) Tanrı'nın cezalandırması vurgusunun çocuk üzerindeki etkisini araştırdıkları çalışmalarında cezalandıran bir Tanrı vurgusunun çocuklara sıklıkla hatırlatılmasının onlarda gazap eden bir Tanrı tasavvuru oluşturmalarına sebep olduğunu ve bu tasavvura sahip çocukların öz suçlama düzeylerinin yüksek; özgüvenin ise düşük olduğu bulgularına ulaşılmıştır. $\mathrm{Bu}$ araştırmada elde edilen sonuca bakıldığında 7 yaşındaki erkek çocuklarda Allah sevgisinin daha ağır bastığı görülmektedir.

8 yaşındaki çocukların Allah'ın nasıl olduğu ile ilgili elde edilen verilere bakıldığında; kız çocukları Allah'ı genel olarak insana benzetmişler veya O'nu herhangi bir şeye benzetmekte zorlanıp hiçbir şeye benzetememişlerdir. Kız çocuklarının Allah’1 tanımlarken; “İnsana benziyor (erkeğe), mavi başörtülü mavi gözlü bayan, benzemiyor, görünmez, bize benzemiyor, gökyüzündeki bir şey, büyük yuvarlak mavi bir şey, bembeyaz şekilsiz bir şey vb." gibi ifadelere yer vermesi bu sonucu destekler niteliktedir. Ulaşılan sonuçla paralel olarak Piaget (2005) 7-8 yaşlarındaki çocukların Tanrı'yı kesinlikle bir insan olarak, insanî özelliklere sahip bir varlık olarak ya da insanların önderi olan bir insan olarak tasavvur ettiklerini belirtmektedir. Öcal'a 
(2004) göre 8 yaşındaki çocuklar Allah'ı somut bir şekilde tasavvur ederler. Ancak bazı çocuklar yavaş yavaş Allah'1 nasıl olduğu bilinmeyen, hiçbir şeye benzemeyen varlık olarak tasavvur ettiklerini belirtmiştir. 8 yaşındaki erkek çocukların Allah'ın nasıl olduğuna ilişkin cevapları incelendiğinde; çocuklar Allah'1 genel olarak insana, sakallı insana benzettikleri görülmüştür. 8 yaşındaki erkek çocukların Allah’ı Kuran kurslarından öğrendikleri sonucu dikkate alındığında bu çocukların Allah’ı anlatan kişiyle özdeşim kurarak Allah tahayyülünü şekillendirdiği görülmektedir. Arslan’a (2004) göre bu dönem çocukların özdeşim kurabilecekleri bir örnek model arayışı içinde oldukları dönemdir. Harms da (1944) 7-12 yaş çocuklarının Tanrı'yı gerçek bir insan olarak düşündüklerini, birçok çocuğun Tanrı'yı din adamı şeklinde tasavvur ettiğini ifade etmektedir (Akt. Clark, 1963). Buna paralel olarak çocuklarda Tanrı tahayyülünü inceledikleri çalışmalarında Roos ve arkadaşları da (2004) okul öncesi dönemindeki çocukların Tanrı tahayyüllerinin şekillenmesinde öğretmenleriyle ilişkilerinin anneleriyle olan ilişkilerinden daha etkili olduğunu bulgusuna ulaşmışlardır.

5-8 yaş çocuklarınınAllah'ınnasılolduğunailişkinalgılarına genelolarakbakıldığında, 5 yaş çocuklarında Allah insana benzetilmektedir yani Allah tahayyülü antropomorfisttir. 6 yaşta ise Allah'ın daha çok büyüklüğü ve iyiliği üzerinde durulduğu gözlenmektedir. 7 yaş çocuklarında ise Allah büyüklük özelliği ve gökyüzü ile eşleştirilmiştir. Bunun sebebi gökyüzünün sonsuza açılması, uçsuz bucaksızlığı ve Tanrı'nın yüceliğine işaret ettiği için metaforik olarak çocuklarda sıklıkla kullanıldığı görülmektedir. 8 yaşta ise insana benzetme tekrar ön plana çıkmaktadır. Bu yaş çocuklarının cami Kuran kurslarına gittikleri görülmektedir. Çocukların Allah'ı insana benzetme nedeninin, Allah'ı anlatan kişilerle Allah'ı özdeşleştirdiklerinden kaynaklandığı düşünülmektedir.

Çocukların Allah'ın özelliklerinin neler olabileceğine ilişkin elde edilen verilere göre, 5 yaşındaki çocuklar genel anlamda Allah'ın özelliklerini bilmediğini savunmuşlardır. 5 yaşındaki kız ve erkek çocukları Allah’ın yarattığını ve kötüleri cezalandırdığını belirtmişlerdir. 5 yaşındaki kız çocuklar, erkek çocuklardan farklı olarak Allah'ın koruyucu özelliğine de vurgu yaptıkları görülmüştür. Fromm’un (2000) çalışmasında çocuklar, Allah'ın onları tıpkı bir anne gibi sevdiği onları koruduğunu belirtmişlerdir. Heller'e (1984) göre kız çocuklarının Tanrı tasavvurları, erkeklerinki gibi, somut gerçeklerle ve olaylarla ilgisinin kurulmasına benzememektedir. Çünkü kız çocuklar, estetik referansları, kendi estetik ve kadınsı özelliklerini Tanrı'ya yansıtmaktadırlar. Bu bilgiye dayanarak 5 yaşındaki kız çocukların annenin özelliği olan koruyuculuğu Tanrı'ya atfederek kendi hemcinslerinin özelliğini Tanrı'ya aktardığı sonucuna ulaşılabilmektedir. 6 yaşındaki çocuklar da 5 yaşındaki çocuklar gibi genel anlamda Allah'ın özelliklerini bilmediklerini savunmuşlardır. 6 yaşındaki kız çocukları Allah'ın iyileri cennete, kötüleri cehenneme attığını, büyük ve güçlü olduğunu belirtmişlerdir. Aynı yaş grubu erkek çocuklar ise Allah'ın yaratma gücünü, büyük olduğu ve kötüleri cezalandırdığını vurgulamıştır. 6 yaşındaki çocukların Allah’ın özelliklerine ilişkin tasavvurlarında cinsiyete ilişkin büyük oranda farklılaşma tespit edilmemiştir. $\mathrm{Bu}$ yaş grubu çocukları Allah'ın nasıl olduğu ve özelliklerinin neler olduğu sorularında tutarlı yanıtlar vererek O'nun büyüklüğünü vurguladıkları görülmektedir. 7 yaşındaki 
çocukların Allah'ın özelliklerine ilişkin verdikleri cevaplar incelendiğinde; bu yaş grubu çocukları da tıpkı 5 ve 6 yaş gruplarında olduğu gibi Allah'ın özelliklerini genel anlamda bilmediklerini ifade ettikleri tespit edilmiştir. 7 yaşındaki kız çocukları O'nun koruyucu olduğuna, yarattığına ve iyilik yaptığına değinmişlerdir. Aynı yaş grubu erkek çocukları ise O'nun yaratma, kötülerden koruma ve kötülere ceza verme gibi özelliklerinin olduğunu savunmuşlardır. 7 yaşındaki kız ve erkek çocukların Allah'ın özelliklerine ilişkin hem olumlu (iyilik yapması, duaları kabul etmesi, koruyucu olması vb.) hem de olumsuz durumları (kötüleri cezalandırma, cehenneme, ateşe atma vb.) betimleyici nitelikte yanıtlar verdiği görülmektedir. Ancak 7 yaş çocuklarının Allah'ın özelliklerine ilişkin verilerine bütün olarak bakıldığında olumlu özelliklere daha fazla yer verdikleri görülmektedir. Elde edilen sonuçlarla paralel olarak Mehmedoğlu (1998) tarafindan gerçekleştirilen bir çalışmada çocukların Allah hakkındaki inançların genel anlamda olumlu olduğu sonucuna ulaşılmıştır. Çocuklara göre Allah onları, zayıf ve güçsüz, suçlu, yalancı, yaramaz olsalar bile onları tıpkı anneleri gibi sevmekte ve bu sevgisi hep devam etmektedir. "Bizi koruduğu için Allah bizi sever" şeklindeki cevapların çokluğu çocukların sevebilecekleri, kendilerini koruyan, ona güvenebilecekleri, dost bir Allah'a inandıklarını ortaya koymaktadır. Bu çalışmada çocukların \% 88,6'sı Allah'ı sevdiğini, buna ilaveten \% 65,9'u Allah'tan korkmadığını söylemektedir. Allah'tan korktuğunu dile getirenlerin ise, korku ifadelerinin çoğunlukla ailelerinden gelen dini inanç ve öğretilerin bir yansıması olduğu sonucuna ulaşılmıştır. 8 yaşındaki çocukların Allah'ın özelliklerine ilişkin yanıtları incelendiğinde, bu çocukların diğer yaş dönemlerinden farklı olarak çoğunlukla Allah'ın özellikleri hakkında bir fikre sahip oldukları ve çocukların oldukça az bir kısmının Allah'ın özelliklerini bilmediklerini belirttikleri görülmüştür. $\mathrm{Bu}$ yaş dönemindeki kız ve erkek çocuklar, Allah'ın yarattığı, iyileri cennete kötüleri cehenneme koyduğu gibi özelliklerin yanı sıra O'nun gece ve gündüzü yarattığı, yağmuru karı yağdırdı̆̆ı, güneş açtırdığı gibi doğaya ilişkin özellikleri de atfettikleri görülmektedir. Araştırma sonuçlarına paralel olarak Yavuz (1983) tarafindan gerçekleştirilen çalışmada da 7-12 yaş aralığındaki çocuklar Allah'ın özelliklerine ilişkin; O her şeyin yaratıcısıdır. O dağları, kuzuları hayvanları yaratmıştır. Bizi korur, her şeyi görür ve bilir. İsterse deprem yapar güçlü binaları yıkar. İyileri ödüllendirip kötüleri cezalandırır gibi hem Allah'ın yaratıcılığı, affediciliği hem de O'nun doğadaki olayları kontrol ettiğine ilişkin ifadelerin bulunduğu görülmektedir.

5-8 yaşındaki çocukların Allah tahayyüllerinin incelendiği çalışmada çocuklara Allah'tan neler istedikleri sorulmuş. 5 yaşındaki kız çocuklar Allah'tan bebek, kar yağması, boya kalemi isterken, erkek çocuklar Allah’tan yemek, oyuncak araba vb. isteklerde bulunmuştur. Bu yaş dönemi özellikleri incelendiğinde 5 yaşındaki çocukların Allah'tan istekleri genel anlamda o andaki ihtiyaç duyduğu maddi unsurları içermektedir. Ayrıca bu çocukların istekleri yalnızca kendilerine yöneliktir. Piaget'e (2005) göre bu yaş dönemindeki çocuklar egosantrik (benmerkezci) özellikler göstermektedir. Bu durum çocukların isteklerinde yalnızca kendilerini ön plana almalarını anlaşılır kılmaktadır. 6 yaşındaki çocukların Allah'tan isteklerine ilişkin ifadelerine bakıldığında kız çocuklar genel anlamda Allah'tan bir şey istemediklerini, O'ndan bir şey istemeye korktuklarını belirtirken dondurma, oyuncak bebek vb. isteklere değinen çocuklar da bulunmaktadır. 
Aynı yaş grubu erkek çocuklarının Allah'tan isteklerine ilişkin ifadelerde; erkek çocuklar da Allah'tan bir şey istemediklerini, köpek istediklerini, cennete gitmek istediklerini belirtmişlerdir. Bu yaş döneminde çocukların Allah'tan istekte bulunmalarılyla ilgili tedirginlik yaşadıkları gözlenmiştir. Bu istemekle ilgili bir çekingenlik olabileceği gibi soyut olduğundan Allah'tan bir şey istenmesinin bilinmemesi veya Allah'tan istemekten korkma şeklinde de olabileceği düşünülmektedir. Çocukların somut işlem döneminde olmaları bu durumun nedeni olabilmektedir. Ayrıca bu yaş dönemindeki çocukların isteklerinde 5 yaş dönemindeki çocuklarda olduğu gibi egosantrik (benmerkezci) özellikler bulunmaktadır. Bu sonuçla paralel olarak David Heller'ın (1984) çocukların Tanrı kavramlarıyla alakalı çalışmasında, 4-6 yaş çocuklarında öncelikli olarak çocuğun refahıyla ilgilenen Tanrı'yla birlikte, dikkat çekecek ölçüde benmerkezciliğe işaret edilmektedir. 7 yaşındaki çocukların Allah'tan istekleri incelendiğinde bu yaş dönemindeki çocuklar da 6 yaş döneminde olduğu gibi genel anlamda Allah'tan bir şey istemediklerini dile getirmişlerdir. Ayrıca 7 yaşındaki kız çocuklar Allah'tan yeni eve taşınma, yemek, ailesini koruması ve notlarının yüksek olması gibi isteklerine değinirken, aynı yaş grubu erkek çocukları ise Allah'tan oyuncak, cennete gitmek, Müslümanların günahının silinmesi gibi isteklerde bulunmuştur. Bu bilgilere bakılarak 7 yaşındaki çocukların kendi ihtiyaçlarına yönelik maddi ihtiyaçlara yer verirken aynı zamanda kendileri dışındaki diğer insanlara (aile) ilişkin isteklere de yer vermeye başlamışlardır. $\mathrm{Bu}$ durum önceki yaş dönemlerinde görülen benmerkezci düşüncenin etkisinin azaldığının göstergesidir. 8 yaşındaki çocukların Allah’tan istekleri incelendiğinde kız çocuklar, Allah'ın ailesini korumasını, mutluluk, herkese yardım etmek, herkesin çalışkan olması vb. isteklerde bulunurken; erkek çocuklar Allah'ın ailesini korumasını, büyümek, anne babaların ölmemesi, kıyametin kopmaması, savaşların bitmesi gibi isteklerde bulunmuşlardır. 5-6-7 yaş çocuklarında o anki ihtiyaçları ön plana çıkmakta ve Allah'tan bu ihtiyaçlarını karşılamalarını istemektedirler. Bu ihtiyaçlar bazen somut, bazen soyut ve psikolojik şekilde karşımıza çıkmaktadır. Örneğin; tavuklu pilav, yemek, kek, ayakkabı, bisiklet gibi somut istekler veya annem babamın yanına gitmeme izin versin, kardeşimin olmasını isterim, kardeşimin annemi üzmemesini isterim, eski arkadaşlarımı görmek isterim gibi soyut ve psikolojik ihtiyaçlar olabilmektedir. Ayrıca isteklerin büyük bir kısmının benmerkezci olduğu görülmektedir yani bir başka deyişle başkaları için değil sadece kendi için istekte bulunmaktadırlar. 8 yaşındaki çocukların isteklerinde ise diğer yaş dönemlerinden (5-6-7 yaş) farklı olarak kendileri dışında aileleri, toplum veya tüm dünya ile ilgili isteklerinin olduğu görülmektedir. Bu sonuca paralel olarak Long, Elkind ve Spilka’ya (1967) göre 5-12 yaş arasındaki süreçte Allah'tan isteklerin, alışkanlıklardan, ezberlenmiş parçalardan ve somut kişisel isteklerden; insancıl ve altruistik (başkalarını düşünme) hassasiyetler içeren daha soyut talepler yönünde bir gelişme seyretmektedir. Çabuk'a (2006) göre ise okul öncesi dönemde şeker ve oyuncak istemek için yapılan benmerkezci isteklerin yerini okul çağında hastalıktan ve felaketten korunma, sevdiklerinin ve ülkenin iyiliği vb. istekleri içeren altruistik istekler almaktadır.

Araştırmada çocukların Allah'tan isteklerinin yaşa ve cinsiyete göre değişimine yer verilmiştir. Sosyo-ekonomik durumun da çocukların Allah'tan olan isteklerini 
etkileyebileceği düşünülmektedir. Ancak bu konuda Şafak (2006) tarafindan 6-11 yaş aralığındaki çocuklarla gerçekleştirilen çalışmada, çocukların sosyo-ekonomik düzeyi ne olursa olsun dua ettikleri zaman çocuklar maddiyata dayanan şeylerden çok sağlik ve mutluluk diledikleri $(\% 82,2)$ sonucuna ulaşılmıştır. Hangi gelir seviyesinde ya da yaş grubunda olursa olsun çocukların bu öncelikli isteklerinin değişmediği görülmüştür.

\section{Öneriler}

Araştırmanın verileri ışığında aşağıdaki önerilerde bulunulabilir;

1. Bu çalı̧̧mada okul öncesi ve ilkokul çağındaki çocukların Allah tahayyülleri hakkında bilgi almak için çocuklarla görüşmeler yapılmıştır. $\mathrm{Bu}$ alanda çalışmayı düşünen araştırmacılar, görüşmenin yanı sıra çeşitli projektif tekniklerden (resim analizi vb.) de faydalanabilir.

2. Çocukların Allah tahayyüllerinin yanı sıra ahiret, peygamber, cennet, cehennem vb. konulardaki tahayyülleri de incelenebilir.

3. Çalışmada 5-8 yaş çocuklarının Allah tahayyülleri incelenmiştir, bu yaş aralığı genişletilebilir.

4. Araştırmada çocukların Allah tahayyüllerini etkileyen yaş, cinsiyet gibi değişkenlere, sosyo-ekonomik faktörler, ailenin dindar olup olmaması vb. farklı değişkenler eklenebilir.

5. Araştırmada belirtildiği üzere çocuklar belirli yaş dönemlerinde bilişsel gelişimleri doğrultusunda Allah tahayyülü oluşturabilmektedir. Bu nedenle çocuklara verilecek din eğitimi çocukların bilişsel seviyesine uygun şekilde planlanmalıdır.

6. Bireylerin diğer varlıklarla olan ilişki biçimlerini etkileyen, temeli çocukluk döneminde atılan ve bireylerin yaşantılarında bu denli öneme sahip olan Allah tasavvurunun çocuklara istendik bir biçimde kazandırılmasında ailenin önemi fark edilmelidir.

7. Aileler, Allah tahayyülünü disiplin kurma amaciyla korkutucu ve cezalandırıcı şekilde betimlemek yerine O'nun bağışlayıcıllı̆ı, affediciliği, sevgisi temele alınarak betimlenmelidir. 


\section{Kaynakça}

Akturan, U. ve Esen, A. (2008). Fenomenoloji. Nitel Araştırma Yöntemleri (Editörler: Baş, T. ve Akturan, U.). Ankara: Seçkin Yayıncılık.

Altaş, N. (2001). İlköğretimde din kültürü ve ahlâk bilgisi öğretimi (1. Bask1). Ankara: Nobel Yayınları.

Arslan, A. (2004). Bir sosyolojik olgu olarak televizyon. Uluslararası İnsan Bilimleri Dergisi, 1(1), $1-17$.

Arthur, J. T. (1979). Çocuk psikolojisi (Çev. Günçe, G.). Ankara: A.Ü.E.F. Yayınları.

Ay, M. E. (1993). Çocuk ve din eğitimi. Yeni Dünya Dergisi, 2, 71.

Ay, M. E. (1994). Din eğitiminde mükafat ve ceza. İzmir: Nil Yayınları.

Barrett J. \& Richert, R. A. (2003). Antropomorphism or preparedness exploring children's God concepts. Review of Religious Research, 44, 300-312.

Bedir, F. N. (2017). Yetişkinlerin çocukluk anılarındaki imgesinin analizi. Hitit Üniversitesi İlahiyat Fakültesi Dergisi, 16(32), 717-740.

Bilgin, B. (1986). Çocuğun manevi eğitimi. Din Öğretimi Dergisi, 10.

Bovet, P. (1958). Din duygusu ve çocuk psikolojisi (Çev. S. Odabaş). Ankara.

Buhari, E. A. M. (1981). El-Camiu's-Sahih (Cilt I-VIII). İstanbul: Çağrı Yayınları.

Clark, W. H. (1961). The psychology of religion. New York: The Macmillan Company.

Corvelyn, J. \& Luyten, P. (2005). Psychodynamic psychologies and religion. New York: The Guiltford Press.

Çabuk, S. K. (2006). İlköğretim öğrencilerinde Allah inancı (Yüksek Lisans Tezi). Sakarya Üniversitesi Sosyal Bilimler Enstitüsü, Sakarya.

Çetin, B. (1991). 6-12 yaşları arasındaki çocuklarda Allah inancının gelişimi (Yayınlanmamış Doktora Tezi). Marmara Üniversitesi Sosyal Bilimler Enstitüsü, İstanbul.

Dickie, J. R., Eshleman A. K., Merasco, D.M., Shepard, A., Wilt, M. V., and Johnson, M. (1997) Parent-child relationships and children's Images of God. Journal for the Scientific Study of Religion, 36(1), 25-43.

Durusoy, A. (1998). Hayal. Türkiye Diyanet Vakfi İslâm Ansiklopedisi, https://islamansiklopedisi. org.tr/hayal Erişim tarihi: 05.02.2019.

Ekiz, D. (2009). Bilimsel Araştırma Yöntemleri. Ankara: Anı Yay.

Evkuran, M. (2007). İslam düşünce geleneğinde Tanrı tasavvuru. İslami İlimler Dergisi, 2(1), 45 62.

Freud, S. (1918). Totem and taboo (Çev. A. A. Brill, Moffat), New York: Yard and Company.

Freud, S. (1927). Bir yanılsamanın geleceği (Çev. H.Z. Kars), İstanbul: Kaynak Yayınları.

Froom, E. (2000). Psikanaliz ve din (Çev. Arıtan, A.). İstanbul: Arıtan Yayınevi. 
Garrod, A., Beal, C. \& Shin, P. (1990). The development of moral orientation in elementary school children. Sex Roles, 22, 13-27.

Goldman, R. J. (1964). Researches in religious thinking. (L. B. Brown Ed.) Psychology and Religion (Middlesex, England: Penguin Education, 1973) adlı eserin içinde, 165-185.

Grimes, C. (2007). God image research: A literature review. Co-published Simultaneously in Journal of Spirituality in Mental Health, 9(3/4), 11-32.

Gürses, İ. \& Kılavuz, M. A. (2011). Erikson'un psiko-sosyal gelişim dönemleri teorisi açısından kuşaklararası din eğitimi ve iletişiminin önemi. Uludă̆ Üniversitesi İlahiyat Fakültesi Dergisi, 20(2), 153-166.

Harms, E. (1944). The development of religious experience in children. The American Journal of Sociology, 50(2).

Heller, D. (1984). The children's God. (Unpublished Doctora Thesis). The University of Michigan.

Heller, D. (1988). The children's God. London: The University of Chicago Press Ltd.

Hertel, B. R. and Donahue, M.J. (1995). Parental influences on God images among Children: Testing Durkheim's Metaphoric Parallelism. Journal for the Scientific Study of Religion, 34(2), 186-199.

Hökelekli, H. (1998). Din psikolojisi. Ankara: TDV Yayınları.

Kay, W. K. \& Ray, L. (2004). Concepts of God: The salience of gender and age. JET, 17(2), 238251.

Kaya, M. (2011). Tasavvur, Türkiye Diyanet Vakfi İslâm Ansiklopedisi, https://islamansiklopedisi. org.tr/tasavvur Erişim Tarihi: 05.02.2019.

Kirkpatrick, L. A. (1992). An attachment-theory approach to the psychology of religion. International Journal for the Psychology of Religion, 2, 3-28.

Kohlberg, L. \& Kramer, R. (1969). Continuities and discontinuities in childhood and adult moral development. Human Development, 12, 93-120.

Kvale, S. (1996). InterViews: An introduction to qualitative research interviewing. Thousand oaks: sage

Ladd, K. L., Mc Intosh, D. N. \& Spilka, B. (1998). Children's God concept: Influences of denomination, age, and gender, The International Journal for the Psychology of Religion, 8, 49-56.

Lincoln, Y. S. \& Guba, E. G. (1985). Naturalistic inquirv. Newbury Park: Sage Publications.

Long, D., Elkind, D., \& Spilka, B. (1967). The child's conception of prayer. Journal for the Scientific Study of Religion, 6, 101-109.

Mehmedoğlu, Y. (1998). Çocuk gelişimi ve eğitimi. İstanbul: Ensar Neşriyat.

Mehmedoğlu, A. U. (2011). Tanrı'yı tasavvur etmek. İstanbul: Çamlıca Yayınları. 
Nelsen, H. M. and Kroliczak, A. (1984). Parental use of the threat "God will punish": replication and extension. Journal for the Scientific Study of Religion, 23(3), 267-277.

Öcal, M. (2004). Okul öncesi ve ilköğretim çağı çocuklarının Allah tasavvurları üzerine bir araştırma. Uludağ Üniversitesi İlahiyat Fakültesi Dergisi, 13(2), 59-80.

Peker, H. (2008). Din psikolojisi. Samsun: Aksiseda Matbaas1.

Piaget, J. (2005). Çocuğun gözüyle dünya. Ankara: Dost Kitabevi Yayınları.

Ritzer, G. (2014). Klasik sosyoloji kuramları. Ankara: De ki Yayınları.

Rizzuto, A. M. (1979). The birth of the living God. Chicago: The University of Chicago Pres.

Roos, S. A. Iedema J. and Miedema, S. (2004). Influence of maternal denomination, God concepts, and child-rearing practices on young children's God concepts. Journal for the Scientific Study of Religion, 43(4), 519-535.

Ruchgy, W. J. (2004). The relationship of mental representation of God to levels of faith development (Unpublished Doctoral Thesis). The University of Detroit Mercy, Detroit, Michigan.

Selçuk, Z. (1997). Eğitim psikolojisi. Ankara: Pegem Yayınları.

Sinanoğlu, A. (2005). Kelam tarihinde Tanrı tasavvurları. Ankara: Avrasya İlahiyat.

Sohn, L. E. (1985). God concepts in children: Beliefs about the attributes of God and implications for Lutheran curriculum and instruction (Unpublished Master Thesis). Marquette University The Faculty of the Graduate School, Milwaukee, Wisconsin.

St. Clair, M. (2004). Human relationships and the experience of God. Oregon: Wipf and Stock Publishers.

Şafak, Ş. (2006). 6-11 yaşşocukların Allah ve peygamberden istek ve beklentileri (Yüksek Lisans Tezi). Uludağ Üniversitesi Sosyal Bilimler Enstitüsü, Bursa.

Takriti, R. A., Barrett, M. \& Buchanan-Barrow, E. (2006). Children's understanding of religion: Interviews with Arab-Muslim, Asian-Muslim, Christian and Hindu children aged 5-11 years. Mental Health, Religion and Culture, 9, 29-42.

Topaloğlu, B. (2006). Allah inancı. İstanbul: İslam Araştırmaları Merkezi (İSAM).

Türk Dil Kurumu (TDK) Güncel Türkçe Sözlük. (2018). Allah maddesi. 13 Mart 2018 tarihindehttp://www.tdk.gov.tr/index.php?option=com_gts\&arama=gts\&guid=TDK. GTS.5aa76f6a880cf8.22345200 adresinden erişildi.

Tütüncü, M. (1987). Çocukta duygu ve heyecan eğitimi. Dokuz Eylül Üniversitesi İlahiyat Fakültesi Dergisi, 4, 265-284.

Vergote, A. (1978). Çocuklukta din (Çev. Erdoğan F.), A.Ü.I.F.D., XXII, 315-329.

Vergote, A. (1999). Din, inanç ve inançsızlık (Çev. Uysal, V.). İstanbul: M. Ü. İlahiyat Fakültesi Vakfi Yayınları.

Vianello, R., Carraro, G. C. \& Lis, A. (1978) L'immagine Della Divinita e L'assimilazione Della Nozioni Religiose Bambini Istituzionalizzatti. Orientamenti Pedagogici, 4, 630-643. 
Vienello, R. T. \& Kalevi, R. D. (2000). Çocukların dini kavramları (Çev. İlhan, Y.). Din Eğitimi Araştırmaları Dergisi, 7, 403-444.

Yavuzer, H. (2001). Eğitim ve gelişim özellikleriyle okul çă̆ı çocuğu, İstanbul: Remzi Kitabevi.

Yavuz, K. (1983). Çocukta dini duygu ve düşüncenin gelişimi. Ankara: Boğaziçi Yayınları.

Yıldırım, A. \& Şimşek H. (2008). Sosyal bilimlerde nitel araştırma yöntemleri (9. Baskı). Ankara: Seçkin Yayıncılık.

Yıldız, M. (2007). Çocuklarda Tanrı tasavvurunun gelişimi. İzmir: İlahiyat Vakfı Yayınları.

Y1ldız, M. \& Arık, R. S. (2011). The image of God in children's compositions, Journal of Islamic Research, 4, 254-278.

Yin, R. K. (1985). Case study research: Design and methods. Beverly Hills, CA: Sage Publications. 